\title{
THE SEASONAL VARIATION IN WEIGHT AND CHEMICAL COMPOSITION OF THE COMMON BRITISH LAMINARIACEAE
}

\author{
By W. A. P. Black, B.Sc., Ph.D., F.R.I.C. \\ Scottish Seaweed Research Association, Musselburgh
}

(Text-figs. I-20)

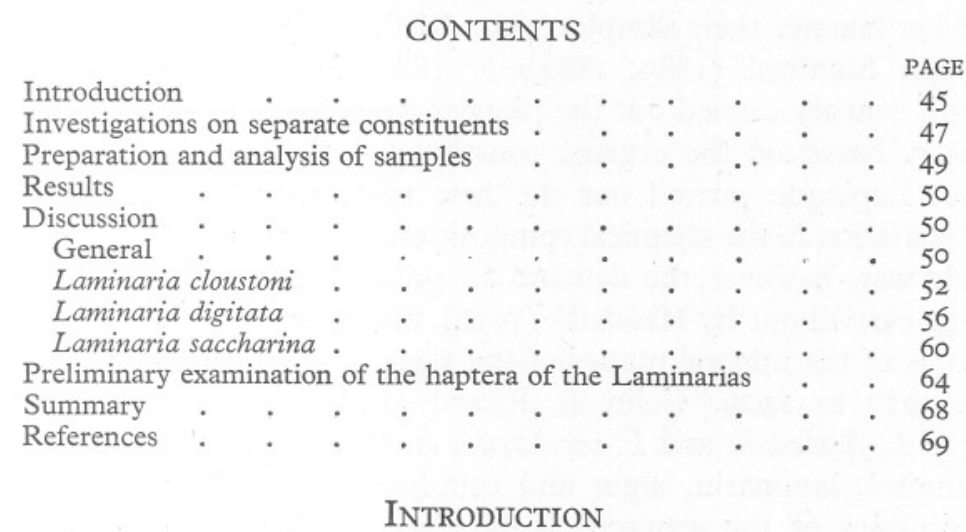

In previous publications the author (Black, I948) has reported the seasonal variation in the total ash, iodine, crude protein, mannitol, laminarin and alginic acid contents of the Laminariaceae, Laminaria cloustoni, L. digitata and L. saccharina, for the 2-year period from November 1944 to October I946.

The work has been continued for a further 2 years and this paper summarizes the seasonal variation in the above constituents, with the exception of iodine, for the period November 1946 to October 1948 inclusive. In addition, the seasonal variation in the fresh weight and dry weight contents has also been recorded.

The algae, in general, undergo such marked variations in chemical composition depending on the season of the year, the habitat, and the depth at which they grow, that any analysis of a sample for which the complete history is not given is of little value.

Cast weed, which usually has all the water-soluble constituents leached out either by the buffeting action of the waves before it is finally deposited on the beach, or by rain while exposed on the shore, may also have undergone appreciable bacterial decomposition, giving a false picture of the composition of the living plant. It is quite possible, too, that the time which elapses between the collection and drying may influence the composition, so that this time, together with the conditions of drying, should also be recorded. 
The present investigation has shown that the method of sampling adopted is relatively sound, and that at any one time surprisingly small differences occur in the composition of individual plants taken from the same habitat, at the same depth, and dried under identical conditions.

The investigation is unique in that the method of sampling prevented the weed from coming into contact with rain, etc., which would affect its composition, and the plants were immediately dried under controlled conditions to reduce any chemical and biological changes to a minimum. Previous workers, on the other hand, do not state how their samples were collected, whether the weed was cut, or whether the samples were those of drift weed, and in what manner their samples were dried.

Although Stanford (I883, I884a, b, I886) in the second half of the nineteenth century carried out the pioneer work and laid the foundations for an industry based on the organic constituents of seaweed, it was not until I9I9 that Lapicque carried out the first systematic investigation into the seasonal variation in the chemical composition of the marine algae. During the first world war, however, the demand for potash led to an intensive investigation being carried out by Hendrick (I9I6), but he was chiefly concerned with the analysis of the mineral matter of the algae.

From 1927 to 1929, Colin \& Ricard (1929, 1930) collected monthly samples of $L$. flexicaulis and L. saccharina and examined them for dry weight, ash, mannitol, laminarin, algin and cellulose. Lunde (1937), investigating the possibilities of the seaweed off the coast of Norway as a source of raw material, collected monthly samples of $L$. digitata from 1935 to 1937 and analysed them for ash, mannitol, alginic acid, laminarin, fucoidin and nitrogen.

Similar investigations have been carried out in Japan by Atsuki \& Tomoda (1926 $a, b)$, in Russia by Kizevetter (1938) and Vedrinskii (1938), and in Eire by Dillon (1943). Our knowledge, however, of the organic constituents of the marine algae is still incomplete. Accurate methods of analysis have been devised for the estimation of mannitol, laminarin, alginic acid and cellulose, while work is continuing on a method for the estimation of fucoidin. The fats and pigments require further investigation. Their nature and relative proportions in the algae are in many cases indeterminate.

No work appears to have been carried out on the algal proteins.

Minor constituents such as fucosterol and the neutral oils are at present being investigated, and it may well be that other valuable constituents have yet to be identified.

The work described in this paper forms part of the programme of research and development on seaweed undertaken by the Scottish Seaweed Research Association.

The author wishes to thank Miss B. Graham and Mr W. Cornhill for assistance with the analytical work and the Association for permission to publish. 


\section{INVESTIGATIONS ON SEPARATE CONSTITUENTS}

In a brief review it is impossible to summarize all the work which has been carried out on the known constituents of the brown algae. The inorganic and several of the organic constituents have attracted the attention of numerous investigators, but it is unfortunate that often the results are somewhat conflicting.

\section{Total ash}

The total ash consists of inorganic salts, presumably in solution in the cell sap, and the cations combined with the organic constituents such as alginic acid and fucoidin. In addition, the ash figure contains salts from the sea water retained on the surface of the plant. The plants were only allowed to drip before drying, since it was not considered advisable to wash off this surface water with distilled water which might affect the composition. Until about I850 the ash of seaweeds, chiefly of the fucoid types, was the sole source of alkali for the soap and glass industries. This kelp industry was then threatened by the Le Blanc process, but as the use of iodine in medicine developed, a new kelp industry arose based on the ash of the laminarias; but this industry is also obsolete. Any future industry, however, based on seaweed will most likely depend on its organic constituents, which are mainly polysaccharide in character.

\section{Trace elements}

The accumulation of trace elements in marine algae, which can be explained by considering alginic acid as an ion-exchange material, has been studied by Cornec (I9I9), Vernadskii (I930), Jones (I922), Öy (I940), and Wilson \& Fieldes (I94I).

A study of the trace elements present in the Laminariaceae and Fucaceae common to Scotland is at present being carried out and the results will be published in a future communication.

\section{Mannitol}

Mannitol, a hexahydric alcohol common to all brown seaweeds, was first detected in L. saccharina by Stenhouse (I844). It appears to be the primary product of photosynthesis, previous workers having found only traces, or the complete absence, of free-reducing sugars. Like the mineral matter, the mannitol is probably all in solution in the cell sap, for if the living plant is put into distilled water the salts and mannitol rapidly diffuse through the cell wall into the surrounding water.

Although there is a recent patent by Berk (I940) on the extraction of mannitol from seaweed, the mannitol of commerce is obtained from manna, or is prepared synthetically by the catalytic reduction of fructose. 


\section{Laminarin}

Laminarin has been the subject of investigation by various workers. It was first described by Schmiedeberg (I885), who isolated it from the Laminariaceae. It has since been studied by Krefting \& Torup (I909), Kylin (I9I3), Gruzewska (I923), Colin \& Ricard (1929), Lunde (I937), Nisizawa (I940), Le Gloahec \& Herter (1940), and Barry (1938, 1939, I94I, I942), and their work has been reviewed by Hassid (I944). Barry (loc. cit.) showed that laminarin consisted exclusively of glucose units, and that after methylation and hydrolysis it gave 2, 4, 6-trimethyl glucopyranose. He concluded that laminarin consisted of a chain of $\beta$-glucopyranose units bent into a spiral form.

Laminarin, therefore, differs fundamentally from starch and cellulose in that the glucose residues are combined by I, 3-glycosidic linkages and not through carbon atoms I and 4 .

The extent of oxidation of laminarin with periodic acid was used by Barry (I942) as an end group assay for this polysaccharide, and the results indicated a chain of sixteen glucose units. This chain length was not in agreement, however, with that obtained by the Haworth-Hirst method which indicated a chain length of about seventy-four glucose units.

The present investigation has shown that laminarin, present only in the frond, can be isolated in two forms, an almost water-insoluble form from L. cloustoni, which separates from cold water, and a more soluble form from L. digitata, which can only be obtained from aqueous solution on the addition of alcohol. The two forms are at present being studied.

It is not yet known what part laminarin plays in the metabolism of the algae.

\section{Alginic acid}

Alginic acid, found in all brown seaweeds, where it is believed to play an important part in the cell wall, was first isolated by Stanford (I883, I884 $a, b$, I886) and has since been studied by the following workers: Hoagland \& Lieb (I9I5), Nelson \& Cretcher (I929), Bird \& Haas (I93I), Dillon \& McGuinness (I93I), Gomez (I933), Barry \& Dillon (I935, I936), Hirst, Jones \& Jones (1939), Stewart \& Lucas (I940), Speakman \& Chamberlain (1944), Astbury (I945), and Wasserman (I949). It has been shown to be a polyuronide composed entirely of D-mannuronic acid.

Dillon \& McGuinness (I93I) believed that the alginic acid in the growing plant was combined with calcium and iron, and that desiccation destroyed the colloidal character of these compounds and rendered them insoluble. Bird \& Haas (I93I), on the other hand, believed that the alginic acid in the cell wall was in two forms: (a) a water soluble form, and $(b)$ the acid in the free state. Recent adsorption experiments carried out by Wasserman (I949), however, have shown that the alginic acid occurs in the cell tissue of brown algae in the form of various metal salts, and is not present as the free acid. 


\section{Crude proteins}

Except for the work of Haas and co-workers (1929, I931, I933, 1938), who succeeded in isolating an octapeptide of glutamic acid, no other work has been carried out on the nitrogen metabolism of the brown algae.

\section{Cellulose}

Although Kylin (I9I3, I9I5, I9I8, I944) had shown that the cell-wall constituents of various seaweeds gave, with iodine and sulphuric acid, the characteristic blue colour of cellulose, considerable doubt existed for some time as to the occurrence of normal cellulose in marine algae. Thus Atsuki \& Tomoda $(\mathrm{I} 926 a, b)$ stated that the greater part of the crude fibre of the laminarias consisted of the hemicelluloses, and that there was no evidence of the normal cellulose, while Ricard (I93I), in the algae examined by him, did not obtain the characteristic reaction of cellulose, as found by Kylin. On the other hand, Naylor \& Russel-Wells (I934) and Dillon \& O'Tuama (I935) demonstrated the existence of normal cellulose in marine algae. Viel's (I939) survey of the literature reveals numerous contradictions, but recent work by Percival \& Ross (I948a) has shown conclusively that the brown algae do contain cellulose which is fundamentally similar to the cellulose of the land plants.

Fats

Except for the work of Russel-Wells (1932) and Takahashi and his coworkers (I933, I935, I939), no other work appears to have been carried out on the fats of the Laminariaceae, and there is no information on the seasonal variation. Russel-Wells (I932) showed that a correlation existed between the fatty constituents and the depth of immersion of the algae. Takahashi et al. have, over a number of years, studied the fats of the indigenous algae of Japan and identified the various fatty acids.

\section{Pigments}

Although an appreciable amount of work has been carried out on the pigments of the Fucaceae, those of the Laminariaceae have received very little attention, the only recent work of a systematic nature being that of Manning \& Hardin (I944).

\section{Preparation and Analysis of Samples}

Each month, the samples of $L$. cloustoni were collected on the reef off Cullipool, Luing Island, in approximately $4 \mathrm{~m}$. of water (D.L.W.O.S.T.), every effort being made to take them from the same spot and at the same depth. The open sea samples of L. saccharina were taken at Rudh-an-Aoil, Shuna Island and the sea-loch samples at Eilean Coltair, Loch Melfort, where the plants were growing in 3-4 m. of water (L.W.). As with L. cloustoni, the samples were obtained by trawling a multi-pronged grapnel for 2 min., hoisting the grapnel and lifting the weed into the boat.

The open-sea samples of L. digitata were taken at Atlantic Bridge and the 
sea-loch samples at Eilean Coltair, Loch Melfort, where the plants were growing in I m. of water (L.W.). The samples were taken by hand at low water, when the plants were partially exposed. With each species, twenty plants were taken, measured and weighed. Two plants were selected for dry-weight determinations, and two were chosen at random for chemical analysis. The plants, separated into stipes and fronds, were draped over racks in a heated shed and dried at a temperature of $25-35^{\circ} \mathrm{C}$. for approximately $48 \mathrm{hr}$., after which they were ground in a Christy and Norris No. 8 Laboratory Mill, fitted with a $\frac{1}{64}$ in. perforated plate screen, giving a powder which practically all passed through a sieve of 90 meshes to the inch. As the analytical methods were evolved it was found that this fine state of division was essential, especially for the method of estimating alginic acid.

The methods of analysis used were those previously employed by the writer (I948).

In the preparation of the samples for analysis, changes in composition due to respiration, etc., were negligible provided drying was carried out immediately after sampling; samples dried rapidly at $80-90^{\circ} \mathrm{C}$. confirmed the results obtained at the temperatures employed in this investigation. On the other hand, plants killed in boiling absolute alcohol before drying, as is the normal procedure in plant analysis, showed considerable loss of mannitol and mineral matter, but it was found possible to kill sections of the laminarias in boiling chloroform without materially affecting the chemical composition.

\section{RESULTS}

The results, calculated on the anhydrous basis for the frond, stipe and whole plant, are given in Figs. I-I9 (pp. 53-67).

Before drying, the plants were divided into stipes and fronds which were weighed separately. From these results each constituent determined in stipe and frond was calculated for the whole plant.

Figs. 2, 8 and I2, giving the seasonal variation in the dry-matter contents of the fronds, the stipes and the whole plants, can be used to recalculate any of the results (expressed on the dry basis) on the fresh-weight basis.

In Fig. 20 (p. 68) the seasonal variation in the fresh weight of L. saccharina from Loch Melfort and Shuna Island is given, while the average figures for the three species are given in Table I.

\section{Discussion \\ General}

In general, the results agree reasonably well with those of the first 2 years investigated (Black, I948), despite the fact that the summer of 1947 was exceptionally good with considerable sunshine, while 1948 was a very poor summer with considerable cloud and rain. Slight differences are occasionally found, 
however, in the spring (March-April). At this period of the year, when a marked increase in the rate of photosynthesis occurs, the plant is actively producing a new frond, while the old frond is wearing away. The composition of the old frond (as shown in Table II) differs somewhat from that of the new frond, to which it is still attached, so that conditions such as rough weather, which influence the shedding of the old frond, will have an effect on the composition of the whole plant.

It would appear, therefore, that when the older part of the frond detaches itself it still contains mannitol and laminarin while the new growth contains no laminarin. This, no doubt, accounts for the sudden drop in laminarin in the spring. The new frond then undergoes a period of rapid growth and laminarin

\section{Table I. Maximum, Minimum and Average Weight of Plants in Grams}

$\begin{array}{llccc} & & \text { Maximum } & \text { Minimum } & \begin{array}{c}\text { Average of } \\ 450 \text { plants }\end{array} \\ \text { L. cloustoni } & \text { Frond } & 936 & 510 & 68 \mathrm{I} \\ & \text { Stipe } & 1787 & 68 \mathrm{I} & \text { II92 } \\ \text { L. saccharina } & \text { Frond } & 1022 & 198 & 595 \\ \text { (open sea) } & \text { Stipe } & 227 & 85 & 198 \\ \text { L. saccharina } & \text { Frond } & 936 & 198 & 595 \\ \text { (loch) } & \text { Stipe } & 227 & 85 & \text { I70 } \\ \text { L. digitata } & \text { Frond } & 1901 & 340 & 965 \\ \text { (open sea) } & \text { Stipe } & 426 & 142 & 255 \\ \text { L. digitata } & \text { Frond } & 823 & 198 & 426 \\ \text { (loch) } & \text { Stipe } & 227 & 85 & 142\end{array}$

TAble II. Composition of the Old and New Frond of LAMINARIA CLOUSTONI COLLECTED AT CULlipool ON I4 ApRIL I947 (DRY BASIS)

$\begin{array}{lccc} & \text { Total ash } & \text { Mannitol } & \text { Laminarin } \\ \text { Old frond } & 38 \cdot 8 & 4 \cdot 0 & 2 \cdot 7 \\ \text { New frond } & 36 \cdot 7 & 8 \cdot 0 & \text { Trace }\end{array}$

is absent. In general, this polysaccharide is almost completely absent when there is rapid growth, i.e. in all the laminarias in the spring, in L. digitata at Atlantic Bridge for the greater part of the year, in the annual Saccorhiza bulbosa already reported, and in all the samples of Macrocystis pyrifera, Nereocystis luetkeana and Lessonia flavicans so far examined.

While the percentage of laminarin in Laminaria cloustoni fronds is over 30 from August to December (dry basis), in L. saccharina and L. digitata it falls rapidly in September, reaching $4.7 \%$ in $L$. saccharina (open sea), $5.9 \%$ in L. saccharina (loch) and $7.5 \%$ in L. digitata (open sea). Parke (1948, and private communication) has found that growth in L. saccharina and L. digitata continues at a greater rate during summer and autumn than in L. cloustoni. With $L$. cloustoni fronds there was practically no growth from July to December in the sublittoral fringe zone, which confirms the author's suggestion that laminarin is generally found when there is 'restricted growth'.

In March, therefore, we find the algae high in proteins and alginic acid with 
the cell sap high in mineral matter and low in carbohydrates, which have been used up during the winter in respiration and probably in the synthesis of amino-acids. In the spring a rapid increase in the rate of photosynthesis occurs accompanied by an increase in the mannitol content and a decrease in the ash content, while rapid growth of the plant results in a decrease in the crude protein content. A decrease in alginic acid occurs as a result of this increase in mannitol. As summarized in Fig. 19, when the results are calculated on the anhydrous basis, ash, proteins and alginic acid are at a maximum and mannitol and laminarin at minimum at the beginning of the spring, while in the autumn the reverse is true.

In the first 2 years investigated, with the exception of L. digitata in I948, a break or flattening out of the mannitol graph for the fronds occurs in JulyAugust of each year. This coincides with (a) a slowing up in the rate of growth, (b) the absence of nutrients in the waters, and (c) the probable period of sporogenesis in the case of $L$. digitata and L. saccharina, so that these factors together with light which is at its maximum intensity at this time are all contributory factors influencing the chemical composition of the algae.

\section{Fronds Laminaria cloustoni}

In May 1947 the dry-weight content is at a minimum of $13.3 \%$ (Fig. 2), laminarin is a minimum of $\mathrm{I} \cdot 0 \%$ (Fig. I), while the total ash is at a maximum $37.6 \%$ (Fig. I). At this period the new frond has probably taken over photosynthesis and the old frond has been cast. The new frond contains $14.2 \%$ mannitol (Fig. 3) and II.8\% crude proteins (Fig. 4), the mannitol having been at minimum in March (6.4\%) and the proteins at maximum (15\%), while the alginic acid was also at a maximum (19.3\%).

As the ash falls to a minimum of $13 \%$ in September-October the dry-weight content reaches a maximum of $32 \%$ in September, the alginic acid a minimum of $8 \%$, and the laminarin a maximum of $32.4 \%$, the ash graph (Fig. I) being the inverse of the laminarin graph.

In I948, maxima and minima of the same order of magnitude occur at approximately the same periods, with the exception of mannitol which is $25 \%$ from June to August compared with a maximum of $22.9 \%$ in August I947. In general, the laminarin, dry weight and mannitol are parallel, showing minima in the spring and maxima in the autumn, while the ash, crude proteins and alginic acid are the reverse, showing maxima in the spring and minima in the autumn.

In Fig. 6 the ash graphs for the 4 years investigated are given and show that the results are reproducible within a month, e.g. an ash content of $30 \%$ occurs in June-July in 1945, I947 and I948, and in July-August in I946.

The only striking difference in the composition of the fronds during the 4 years now investigated is in the laminarin content which progressively increases each year from $29 \%$ in 1945 to $34 \%$ in 1948 , while later work to be 


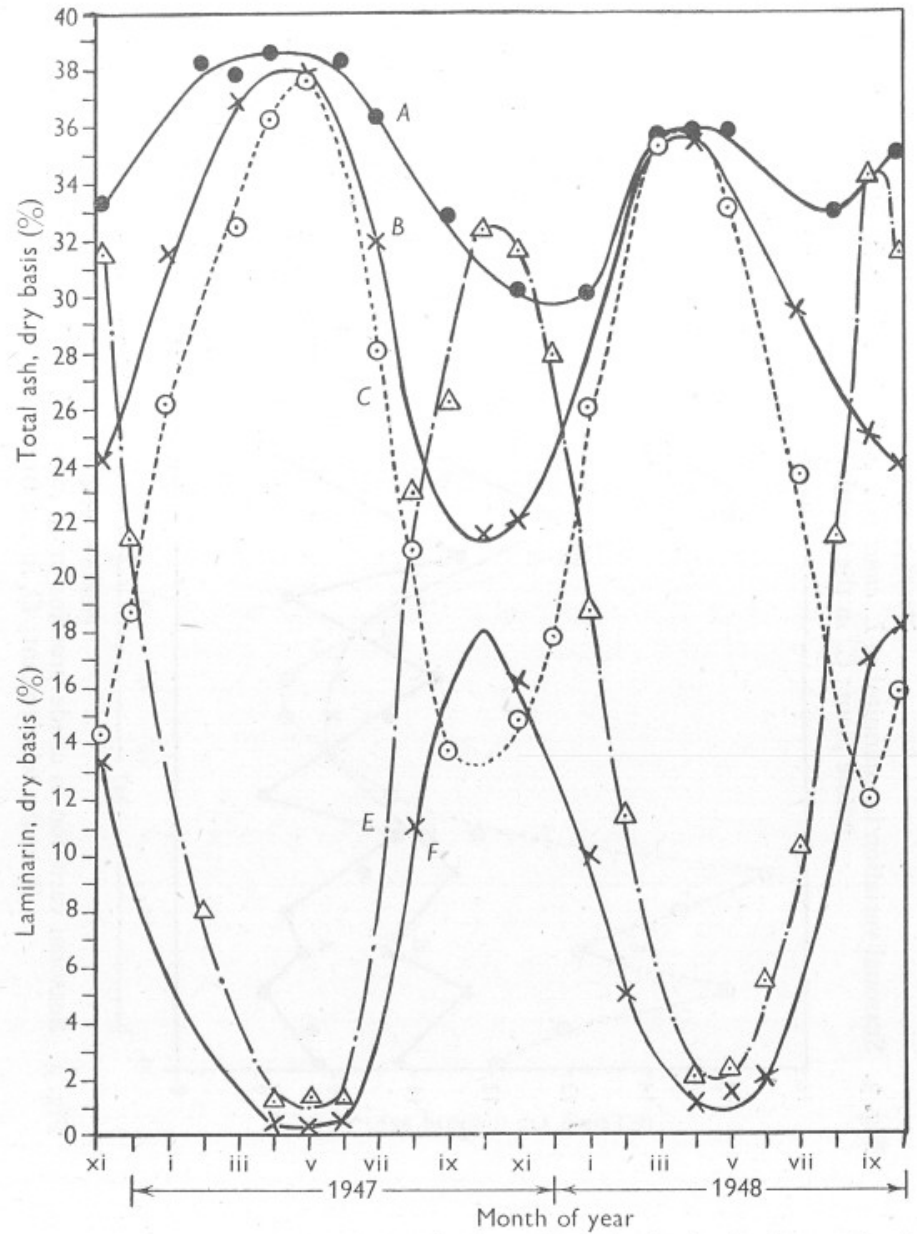

Fig. I. Seasonal variation in total ash and laminarin in L. cloustoni. A, total ash in the stipes; $B$, total ash in whole plant; $C$, total ash in the fronds; $E$, laminarin in the fronds; $F$, laminarin in the whole plant.

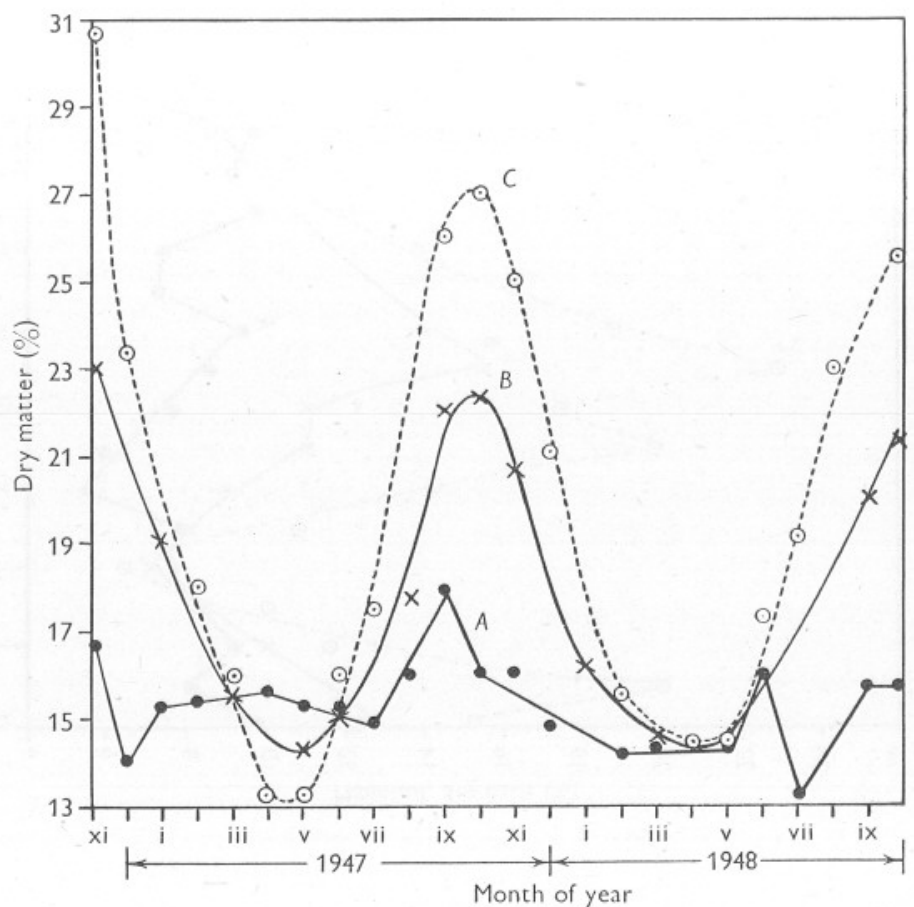

Fig. 2. Seasonal variation in dry matter in L. cloustoni. $A$, in the stipes; $B$, in the whole plants; $C$, in the fronds. 


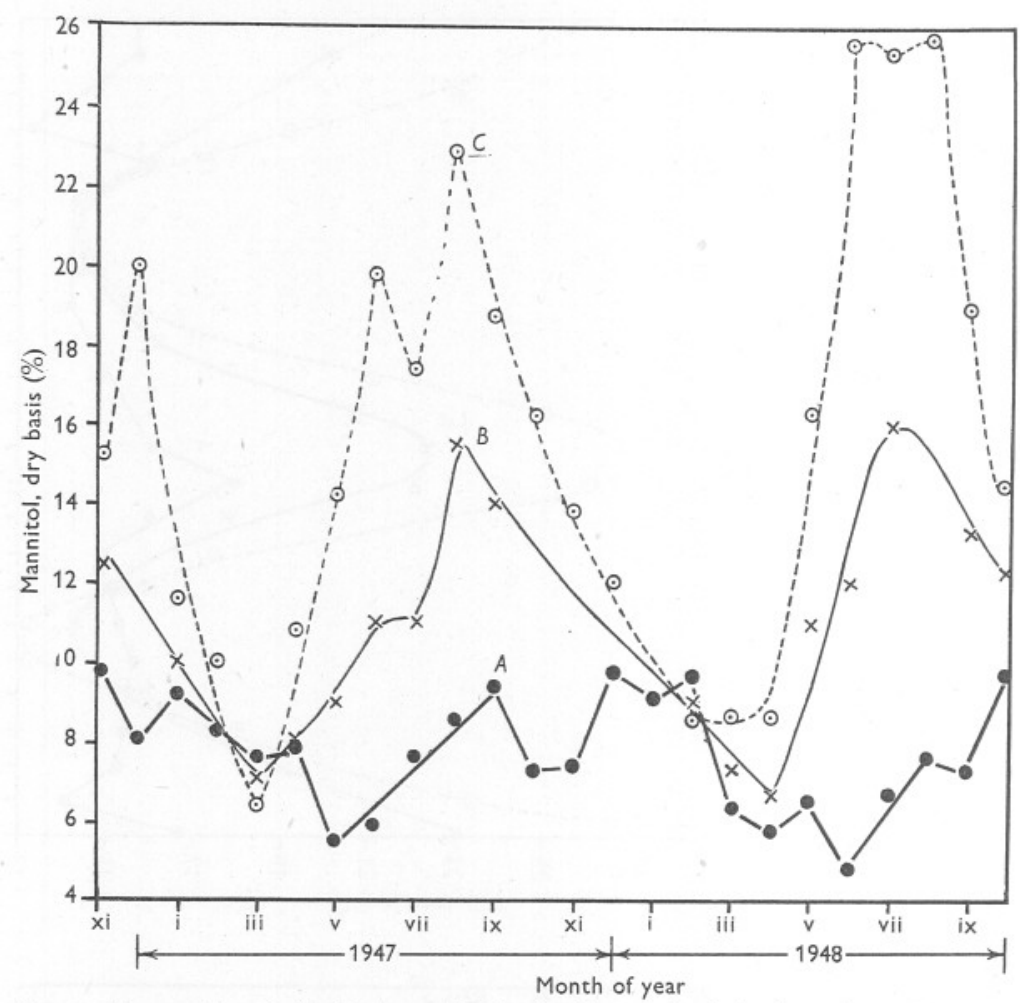

Fig. 3. Seasonal variation in mannitol in L. cloustoni. $A$, in the stipes; $B$, in the whole plant; $C$, in the fronds.

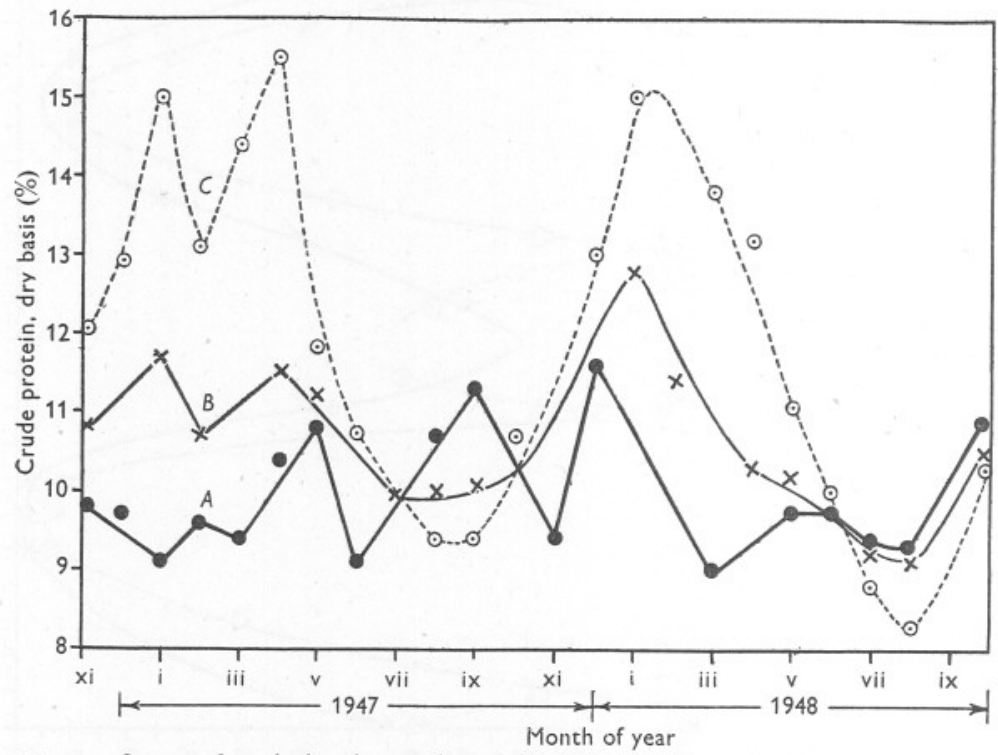

Fig. 4. Seasonal variation in crude proteins in L. cloustoni. A, in the stipes; $B$, in the whole plant; $C$, in the fronds. 


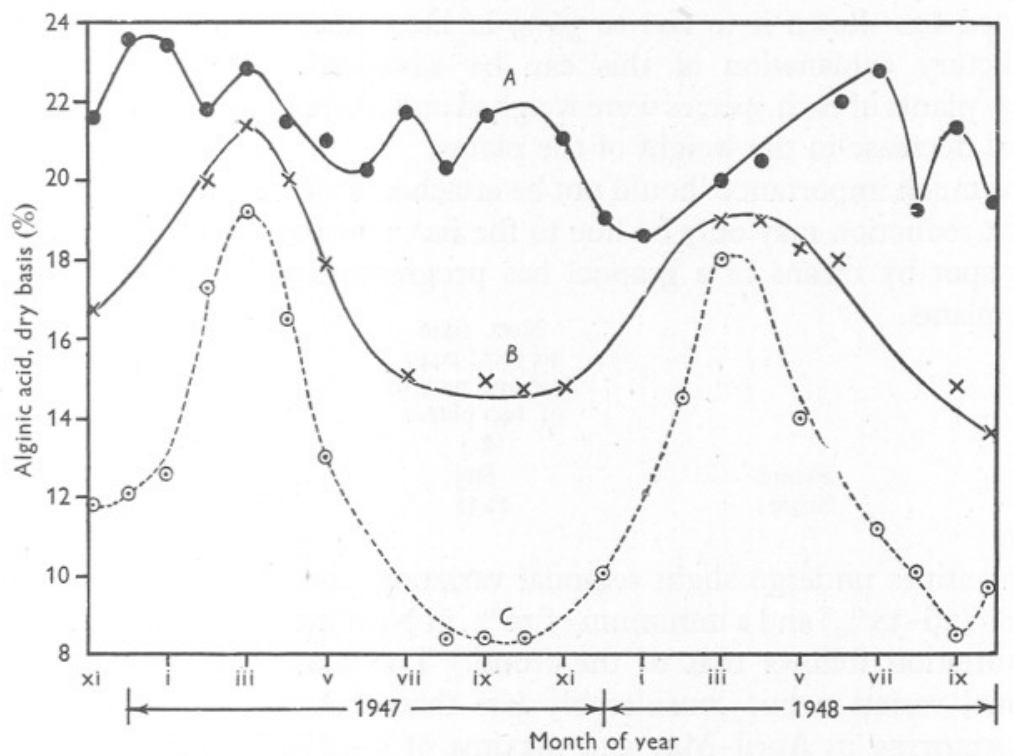

Fig. 5. Seasonal variation in alginic acid in L. cloustoni. $A$, in the stipes; $B$, in the whole plant; $C$, in the fronds.

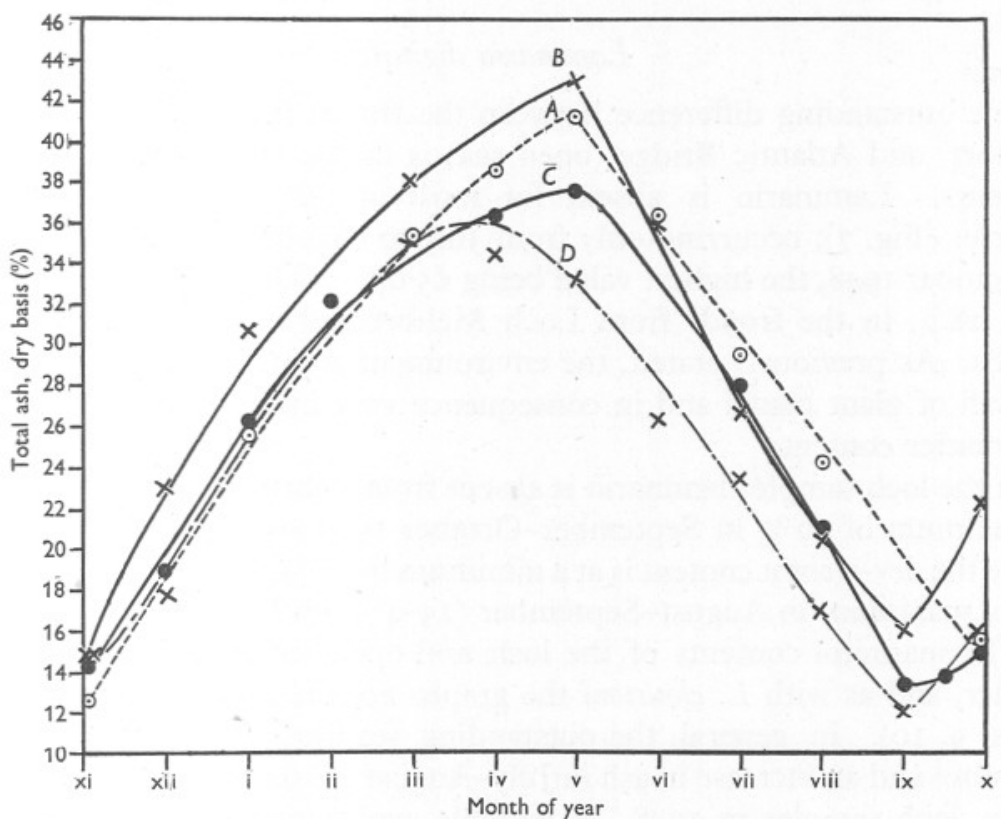

Fig. 6. Seasonal variation in total ash in $L$. cloustoni fronds. A, 1944-1945; $B$, I945-I946; $C$, I946-I947; $D$, I947-I948. 
reported has shown it to rise to $36 \%$ in December I948-January I949. No satisfactory explanation of this can be advanced. However, each month twenty plants of each species were weighed and the results indicate a progressive annual decrease in the weight of the plants.

Too much importance should not be attached to such figures, as the apparent weight reduction may only be due to the fact that repeated sampling from the same spot by means of a grapnel has progressively removed the larger and older plants.

Stipes

Nov. I946
to Oct. I 947
Average weight
of 240 plants
(g.)
693
I23I

Nov. I 947
to Oct. I 948
Average weight
of 240 plants
(g.)
656
II 4 I

The stipes undergo slight seasonal variation, the ash being at a maximum in May (36-38\%) and a minimum of $30 \%$ in November-December; in general, the variation follows that of the frond. The mannitol graph also shows seasonal variation but considerably less than that in the fronds, minima of $5 \%$ occurring in April-May and maxima of $9-10 \%$ in September-October. The dry weight content, however, shows very little variation (I3-I8\%; Fig. 2).

The alginic acid shows no regular variation and fluctuates between 19 and $24 \%$.

\section{Fronds Laminaria digitata}

The outstanding difference between the fronds from Eilean Coltair (Loch Melfort) and Atlantic Bridge (open sea) is in the laminarin and dry-weight contents. Laminarin is absent for most of the year from the open-sea samples (Fig. 7), occurring only from July to October 1947 and from August to October I948, the highest value being $15.6 \%$ in October 1948 , as compared with $28 \%$ in the fronds from Loch Melfort and over $30 \%$ in L. cloustoni fronds. As previously stated, the environment at Atlantic Bridge favours the growth of giant plants and in consequence very little variation occurs in the dry matter content.

In the loch samples laminarin is absent from February to April, and reaches a maximum of $20 \%$ in September-October 1947 and $28 \%$ in October 1948, while the dry-weight content is at a minimum from January to March (II-I $\%$ ) and a maximum in August-September (23-4\%) in both 1947 and 1948 .

The mannitol contents of the loch and open-sea samples are remarkably similar, and as with $L$. cloustoni the graphs are the inverse of the ash graphs (Figs. 9, I0). In general, the outstanding features are a temporary drop in mannitol and an increase in ash in July-August of 1947 , and at the same period in the loch samples in 1948. A possible explanation of this is advanced in a recent publication (Black \& Dewar, 1949).

The crude-protein graphs (Fig. I5) are very similar for loch and open-sea samples, exhibiting maxima of $12-14 \%$ between February and April and 


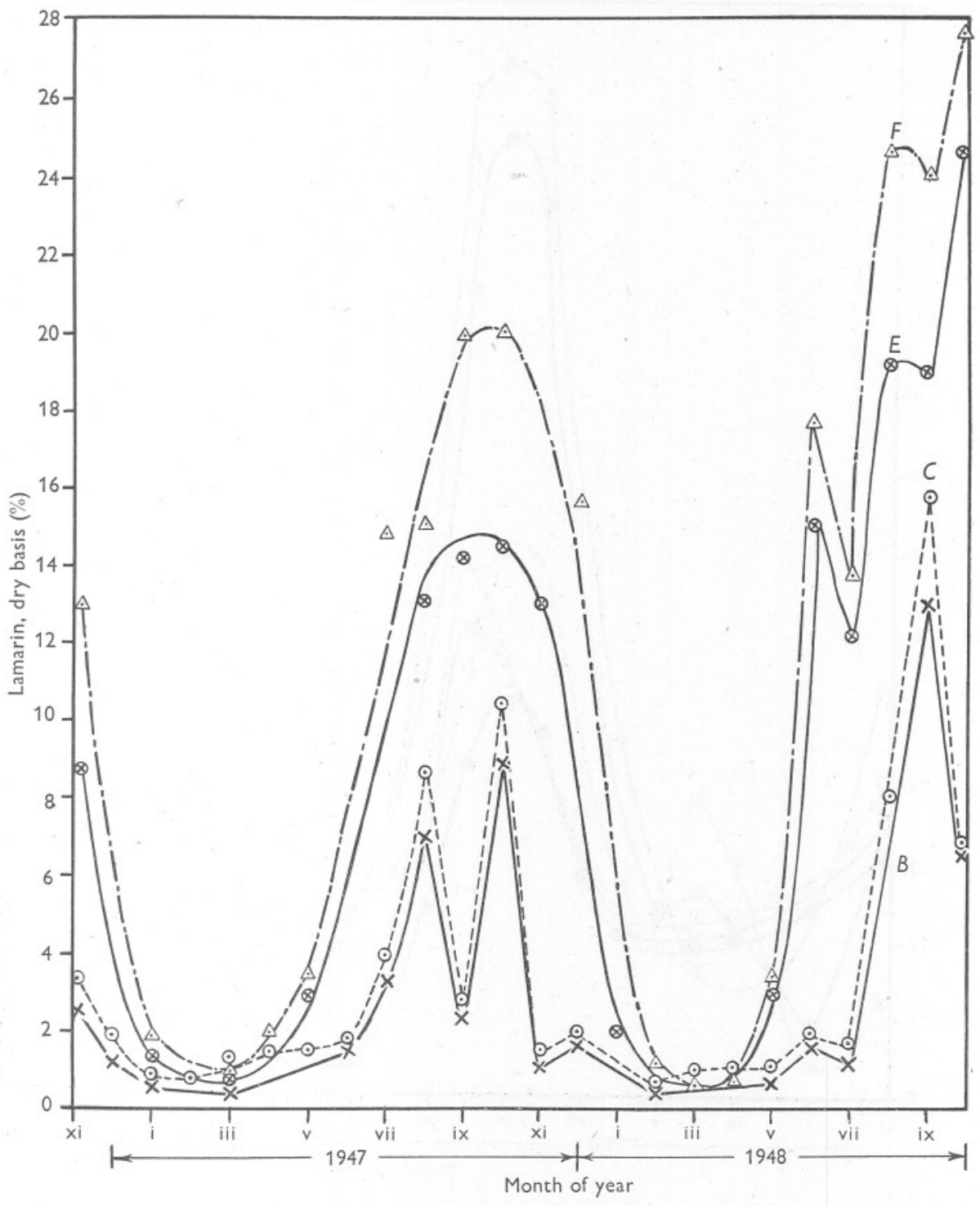

Fig. 7. Seasonal variation in laminarin in $L$. digitata. $B$, open-sea whole plant; $C$, open-sea fronds; $E$, loch whole plant; $F$, loch fronds. 


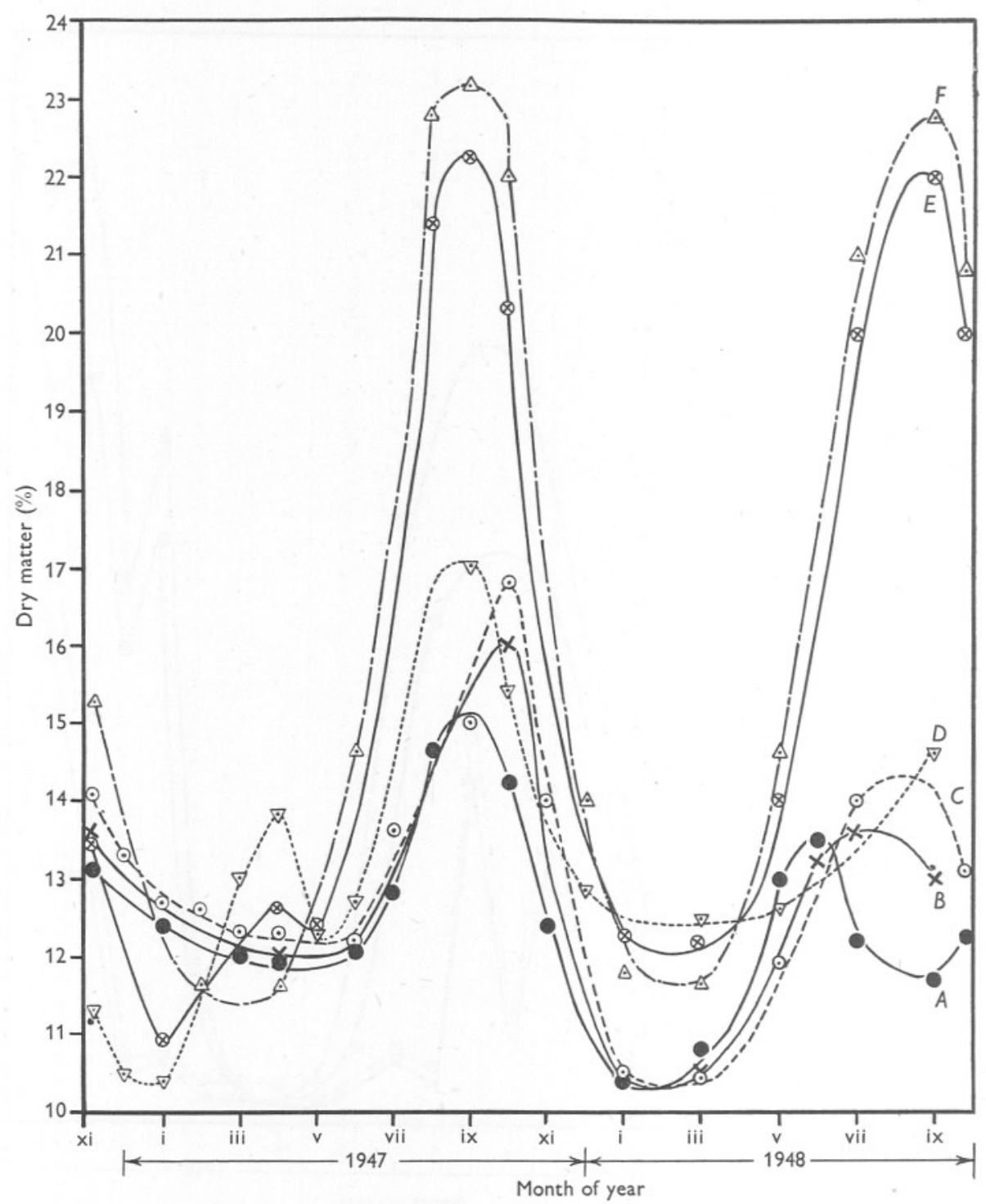

Fig. 8. Seasonal variation in dry-matter content in $L$. digitata. $A$, open-sea stipes; $B$, opensea whole plant; $C$, open-sea fronds; $D$, loch stipes; $E$, loch whole plant; $F$, loch fronds. 


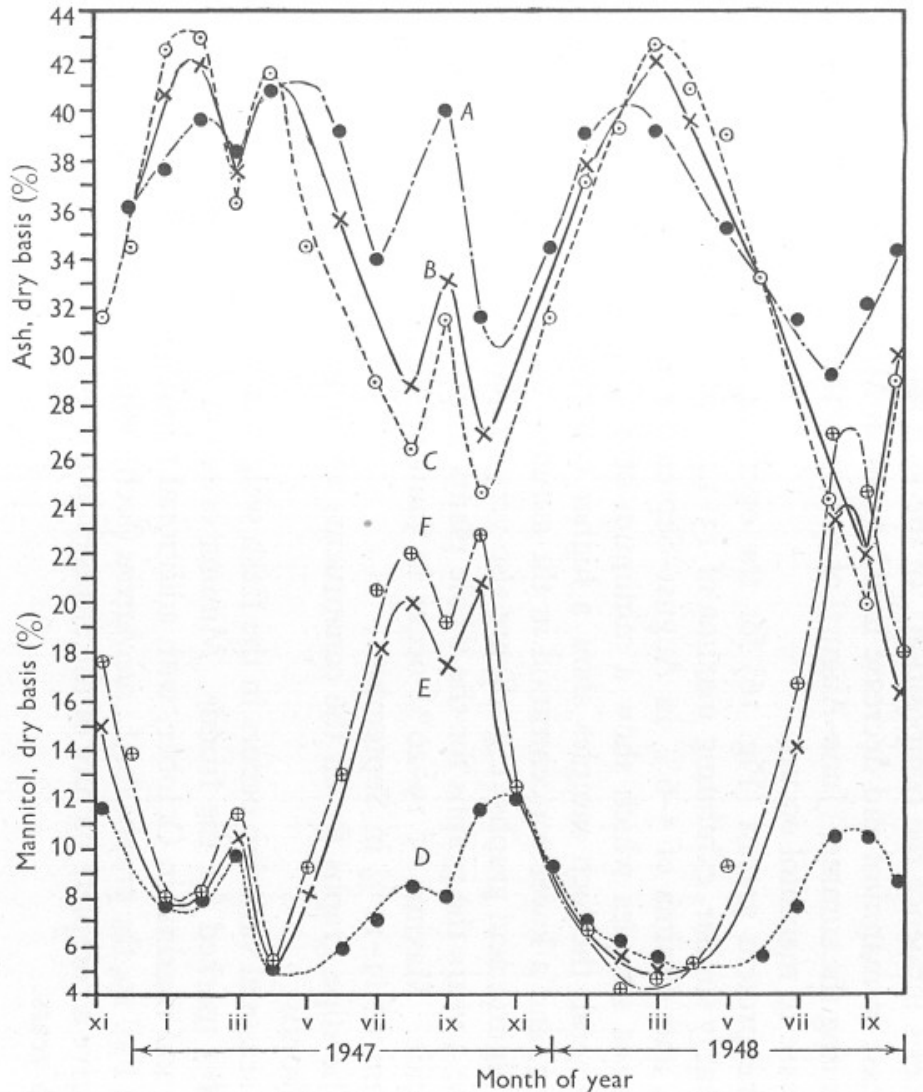

Fig. 9. Seasonal variation in ash and mannitol in L. digitata (open sea). $A$, ash in the stipes; $B$, ash in the whole plant; $C$, ash in the fronds;
$D$, mannitol in the stipes; $E$, mannitol in whole plant; $F$, mannitol in the fronds.

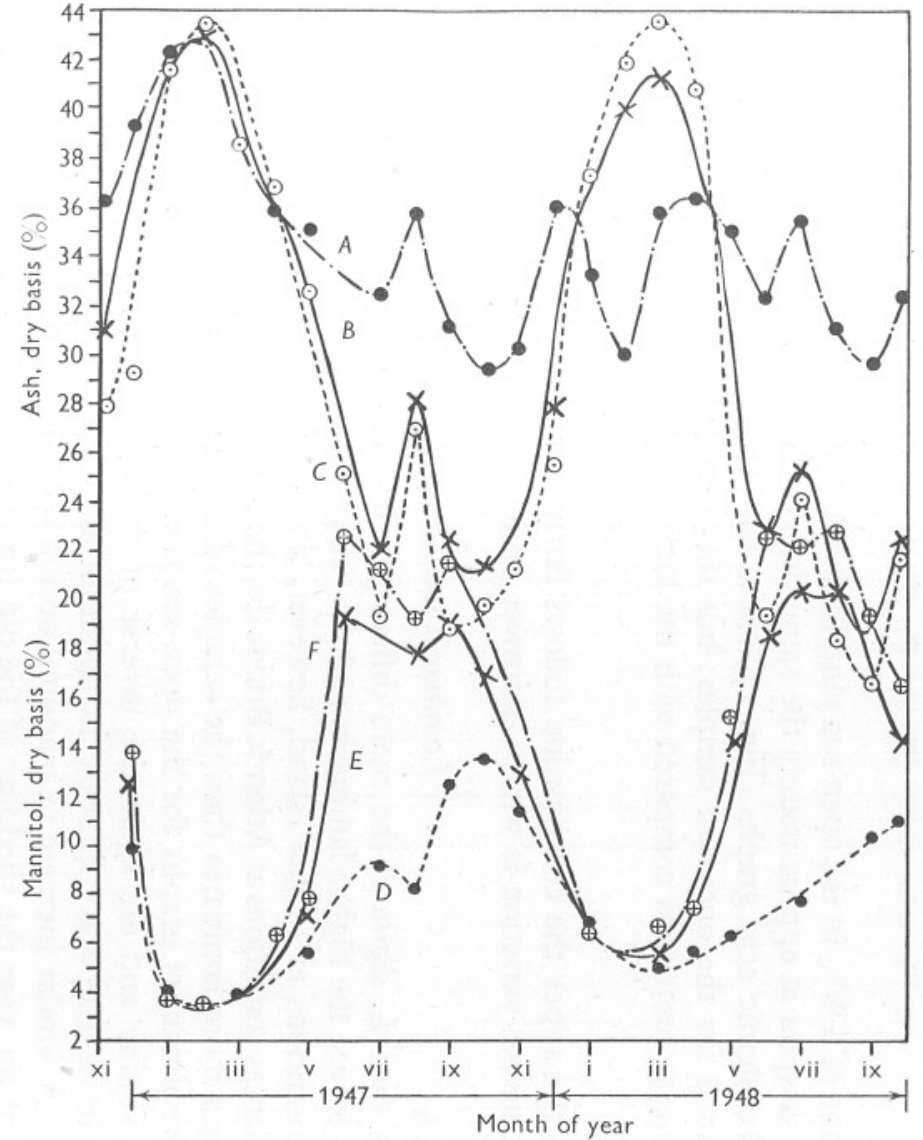

Fig. Io. Seasonal variation in ash and mannitol in L. digitata (loch). $A$, ash in the stipes; $B$, ash in whole plant; $C$, ash in the fronds; $D$, mannitol in the stipes; $E$, mannitol in the whole plant; $F$, mannitol in the fronds. 
minima of 6-8\% in the open-sea samples in August-October, and $4-6 \%$ in the loch samples at approximately the same time of the year.

The alginic acid graphs (Fig. I7) show that, in general, higher values are obtained for the open-sea samples, but this may be the result of the lower laminarin content as compared with the loch samples.

\section{Stipes}

In the stipes the composition follows fairly closely that of the fronds but the seasonal variation is within narrower limits.

\section{Fronds Laminaria saccharina}

As with $L$. digitata, the main differences between the open-sea and loch samples are the higher laminarin and dry-weight contents of the loch samples. As conditions at Shuna Island, however, do not differ so much from Loch Melfort as conditions at Atlantic Bridge do, the open-sea samples of L. saccharina contain more laminarin than the samples of L. digitata from Atlantic Bridge.

The mannitol graphs for the open-sea and loch samples (Figs. I3, I4) are very similar and are again the inverse of the ash graphs. In the open-sea samples a temporary increase in mannitol and drop in ash occur in March 1947. A similar increase in mannitol occurs again in March 1948, but at this time of the year the shedding of the old frond and a rapid increase in photosynthesis influence the composition. In the loch samples a similar temporary increase in mannitol and decrease in ash occur in March I947.

During the summer (June-August) of each year the characteristic temporary decrease in mannitol occurs.

The protein graphs (Fig. I6) for the open-sea and loch samples are remarkably similar, exhibiting maxima of $13-14 \%$ in February-March of each year, and minima of $5-6 \%$ in August-September with the exception of the open-sea samples which show a minimum of $8 \%$ in July-September 1947. In general, the loch samples show a higher concentration of proteins in the spring, and a lower concentration in the autumn, than the open-sea samples. The alginic acid graphs (Fig. I8) are also very similar, and for the greater part of the 2 years the graphs for the whole plants from the two localities actually coincide. Maxima of $19-20 \%$ occur in January-February of each year and minima of $\mathrm{II}-\mathrm{I}_{2} \%$ in September.

The stipe graphs for all the constituents are in general parallel to those of the fronds.

A seasonal variation occurs in the fresh weight of the plants (Fig. 20) which is most marked for the fronds. Minima occur in January-February of each year and maxima in October, with additional maxima in July I948.

In Fig. 19, the graphs for L. saccharina (loch), whole plant, are superimposed and give a complete picture of the changes in composition which occur during the 2 years. 


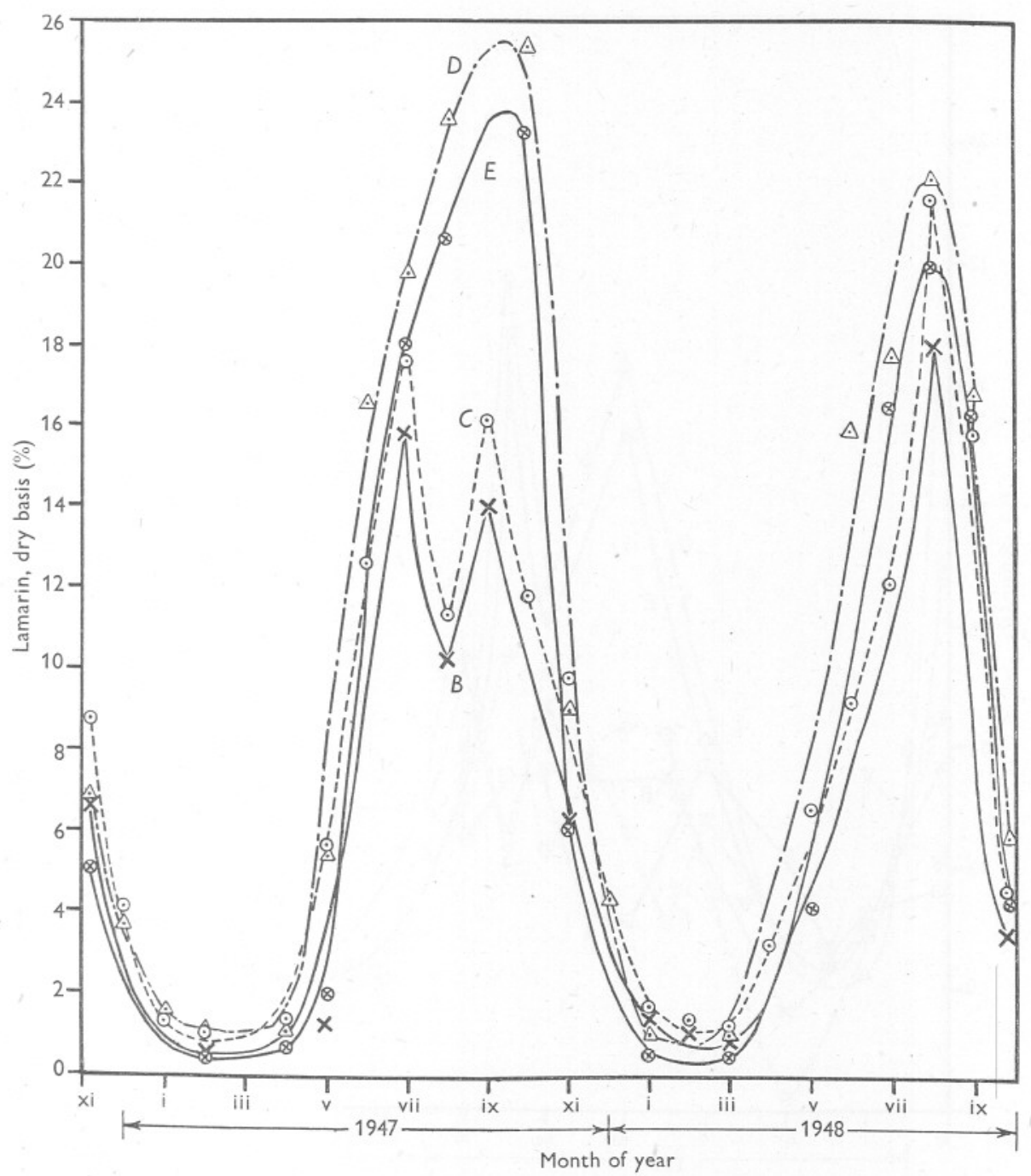

Fig. II. Seasonal variation in laminarin in L. saccharina. $B$, in the open-sea whole plants; $C$, in the open-sea fronds; $E$, in the loch whole plants; $D$, in the loch fronds. 


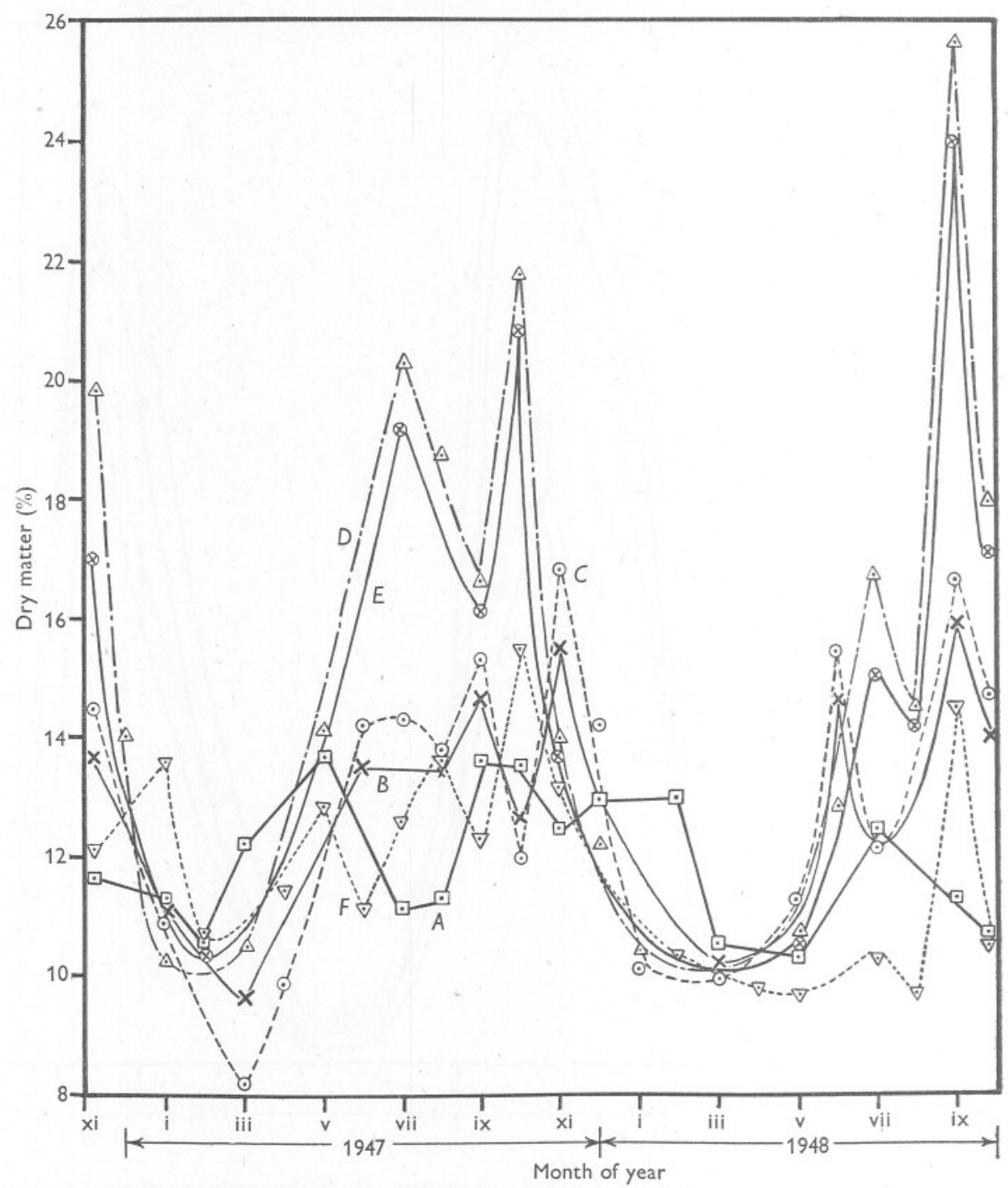

Fig. I2. Seasonal variation in dry matter in L. saccharina. $A$, in the open sea stipes; $B$, in the open-sea whole plants; $C$, in the open-sea fronds; $D$, in the loch fronds; $E$, in the loch whole plants; $F$, in the loch stipes. 


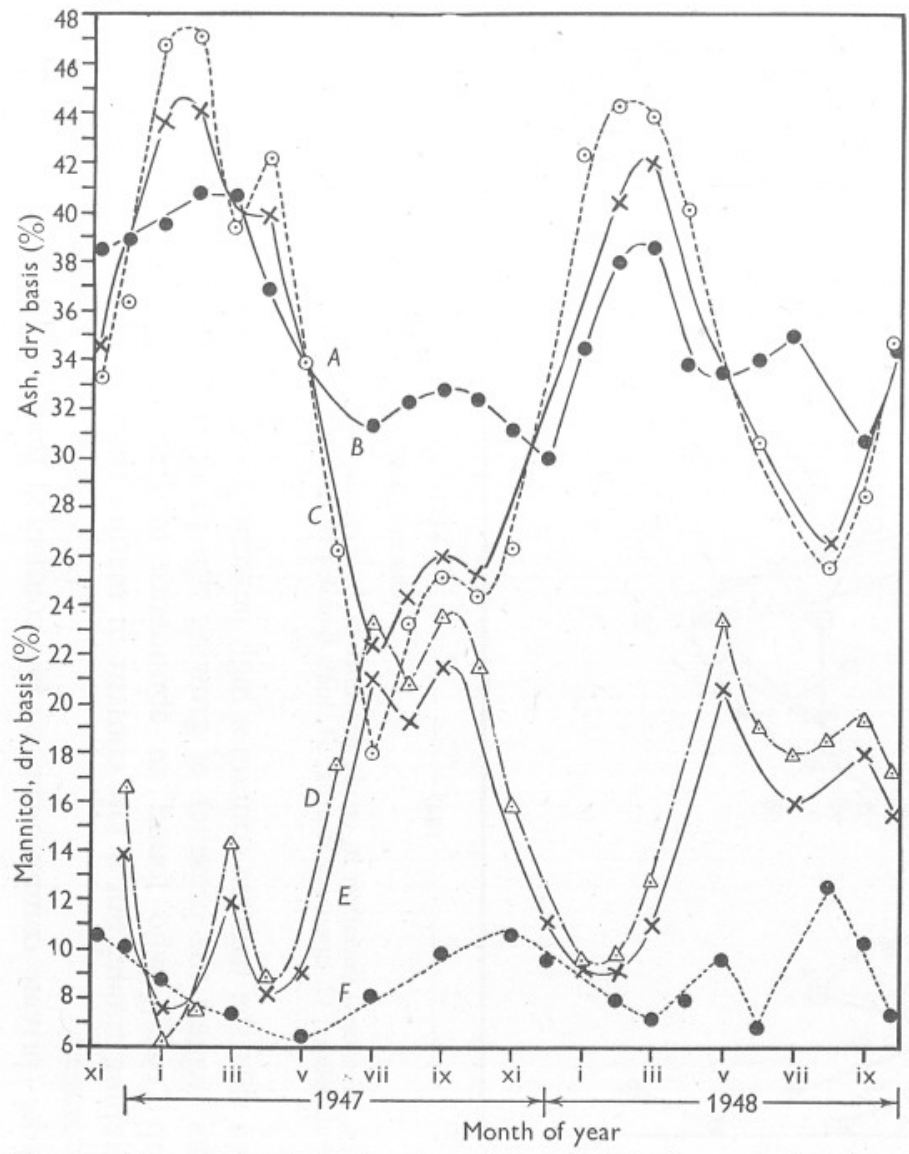

Fig. I3. Seasonal variation in ash and mannitol in L. saccharina (open sea). $A$, ash in the stipes; $B$, ash in the whole plant; $C$, ash in the fronds; $D$, mannitol in the fronds; $E$, mannitol in the whole plant; $F$, mannitol in the stipes.

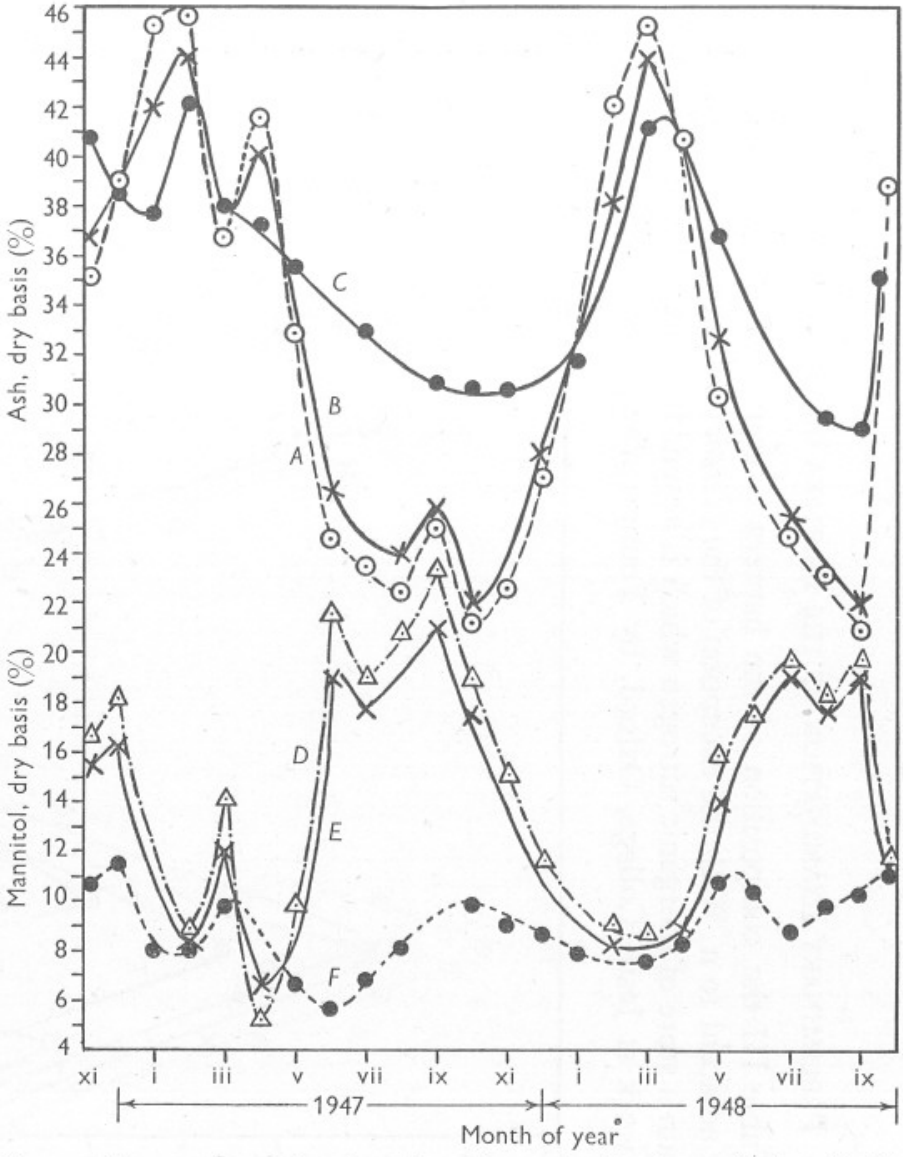

Fig. I4. Seasonal variation in ash and mannitol in L. saccharina (loch). $A$. ash in the fronds; $B$, ash in the whole plant; $C$, ash in the stipes; $D$, mannitol in the fronds; $E$, mannitol in the whole plant; $F$, mannitol in the stipes. 


\section{Preliminary EXamination of the Haptera OF THE LAMINARIAS}

In Table III the composition of the haptera is compared with that of the stipe adjacent to it. With the exception of the Nereocystis stipe the haptera all contain a store of inorganic nitrogen which is absent from the adjacent stipes, and work at Jesus College, Oxford, by Young (private communication) has

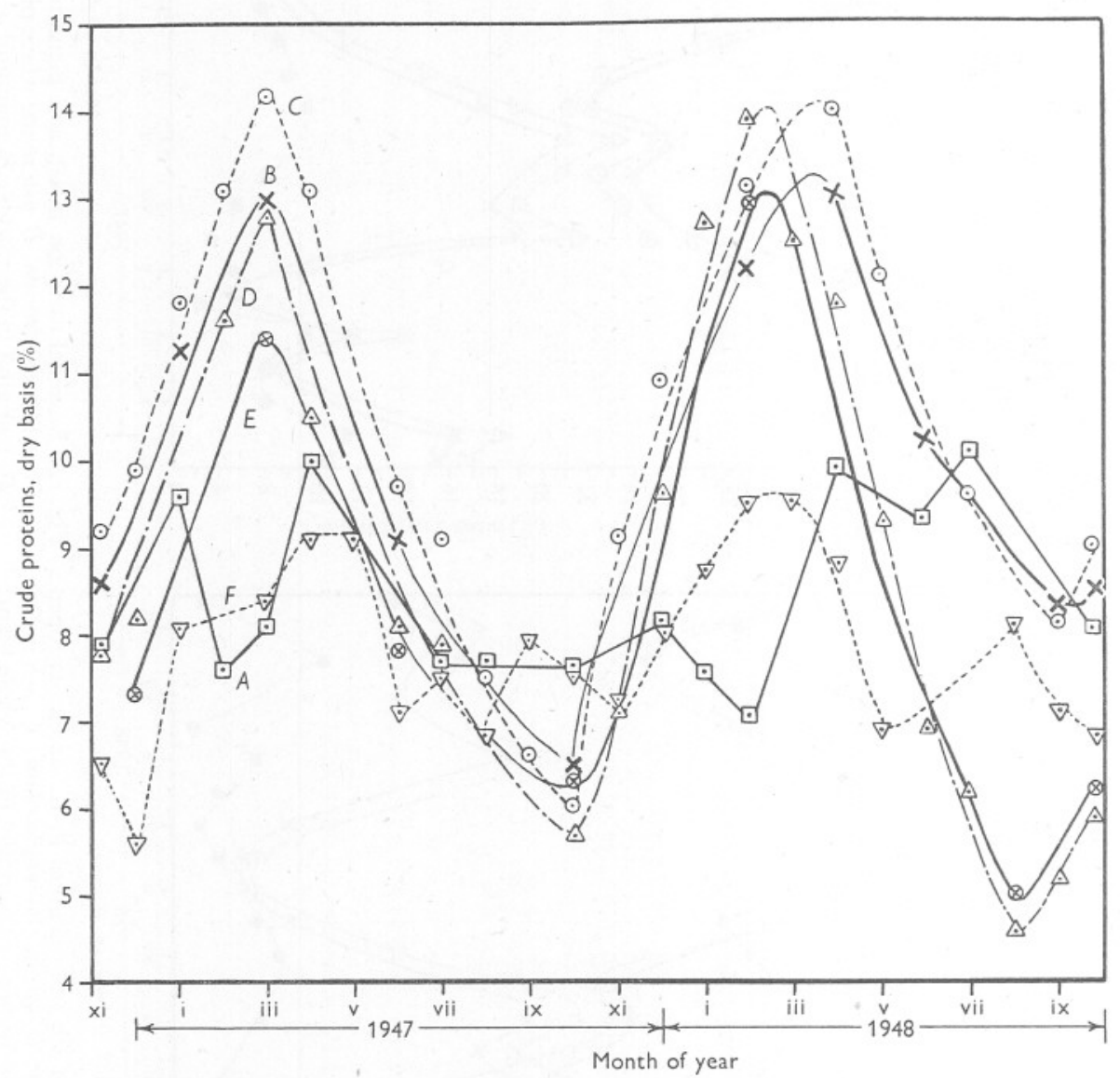

Fig. I5. Seasonal variation in crude proteins in $L$. digitata. $A$, open-sea stipes; $B$, open-sea whole plant; $C$, open-sea fronds; $D$, loch fronds; $E$, loch whole plants; $F$, loch stipes.

shown that the haptera contain a high percentage of free amino-acids. These results suggest the presence of growing tips in agreement with the result of Allsop (I948), who found an abundance of free amino-acids in actively developing tissue, but a low content in mature tissues not specially adapted for storage.

Parke (private communication) has confirmed that the haptera develop as 
TABLE III. CoMposition OF THE HAPTERA OF THE LAMINARIACEAE LAMINARIA CLOUSTONI, L. DIGITATA AND L. SACCHARINA, AND NEREOCYSTIS LUETKEANA (DRY BASIS).

\begin{tabular}{|c|c|c|c|c|c|c|c|}
\hline Sample & $\begin{array}{l}\text { Date and place } \\
\text { of collection }\end{array}$ & $\begin{array}{l}\text { Total } \\
\text { ash }\end{array}$ & Mannitol & Laminarin & $\underset{\text { acid }}{\text { Alginic }}$ & $\begin{array}{l}\text { Crude } \\
\text { proteins }\end{array}$ & $\begin{array}{l}\text { In- } \\
\text { organic } \\
\text { nitrogen }\end{array}$ \\
\hline $\begin{array}{l}\text { L. cloustoni, } \\
\text { holdfast }\end{array}$ & $\begin{array}{l}\text { July r948, } \\
\text { Cullipool }\end{array}$ & $34 \cdot I$ & $6 \cdot 0$ & $<\mathrm{I} \cdot \mathrm{O}$ & 6.6 & 14.0 & 0.17 \\
\hline $\begin{array}{l}\text { L. cloustoni, } \\
\text { stipe adjacent }\end{array}$ & $\begin{array}{l}\text { July r948, } \\
\text { Cullipool }\end{array}$ & $35 \cdot 9$ & $6 \cdot 7$ & $<\mathrm{I} \cdot \mathrm{O}$ & $22 \cdot 9$ & $9 \cdot 4$ & Nil \\
\hline $\begin{array}{l}L \text {. digitata, } \\
\text { holdfast }\end{array}$ & $\begin{array}{l}\text { Oct. I948, } \\
\text { Atlantic Bridge }\end{array}$ & $32 \cdot 4$ & $8 \cdot 4$ & $<\mathrm{I} \cdot \mathrm{O}$ & I $8 \cdot 8$ & 15.3 & 0.20 \\
\hline $\begin{array}{l}\text { L. digitata, } \\
\text { stipe adjacent }\end{array}$ & $\begin{array}{l}\text { Oct. I948, } \\
\text { Atlantic Bridge }\end{array}$ & $34 \cdot 2$ & $8 \cdot 6$ & $<\mathrm{I} \cdot \mathrm{O}$ & $30 \cdot 6$ & $8 \cdot I$ & Nil \\
\hline $\begin{array}{l}\text { L. saccharina, } \\
\text { holdfast }\end{array}$ & $\begin{array}{l}\text { Oct. I948, } \\
\text { Shuna Island }\end{array}$ & $37 \cdot 3$ & $7 \cdot 4$ & $<\mathrm{I} \cdot \mathrm{O}$ & $7 \cdot 5$ & I5.9 & 0.18 \\
\hline $\begin{array}{l}\text { L. saccharina, } \\
\text { stipe adjacent }\end{array}$ & $\begin{array}{l}\text { Oct. I948 } \\
\text { Shuna Island }\end{array}$ & $34 \cdot 6$ & $7 \cdot 3$ & $<\mathrm{I} \cdot \mathrm{O}$ & 24.9 & $9 \cdot I$ & Nil \\
\hline $\begin{array}{l}\text { N. luetkeana, } \\
\text { holdfast }\end{array}$ & $\begin{array}{l}\text { Oct. r948, San } \\
\text { Juan, Wash., } \\
\text { U.S.A. }\end{array}$ & $39 \cdot 0$ & $\mathrm{I} \cdot 2$ & $<\mathrm{I} \cdot \mathrm{O}$ & $6 \cdot 9$ & I6.3 & $0.4 \mathrm{I}$ \\
\hline $\begin{array}{l}N \text {. luetkeana, } \\
\text { stipe adjacent }\end{array}$ & $\begin{array}{l}\text { Oct. 1948, San } \\
\text { Juan, Wash., } \\
\text { U.S.A. }\end{array}$ & $40 \cdot 8$ & $I \cdot 2$ & $<\mathrm{I} \cdot \mathrm{O}$ & $\mathrm{I}_{3} \cdot 8$ & $5 \cdot 8$ & 0.29 \\
\hline
\end{tabular}

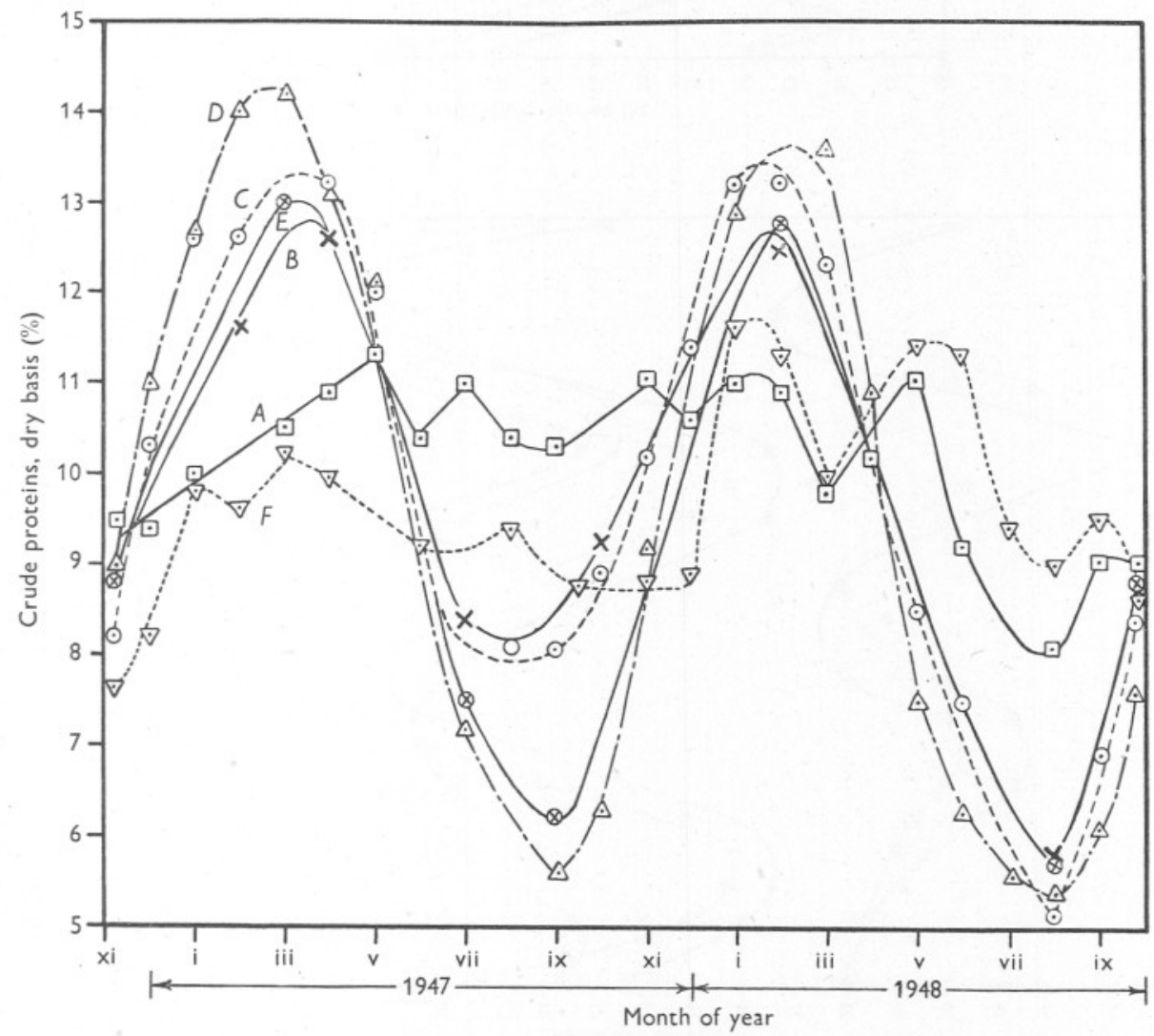

Fig. I6. Seasonal variation in crude proteins in L. saccharina. $A$, open-sea stipes; $B$, open-sea whole plants; $C$, open-sea fronds; $D$, loch fronds; $E$, loch whole plants; $F$, loch stipes.

JOURN. MAR. BIOL. ASSOC. vol. XXIX, I950 


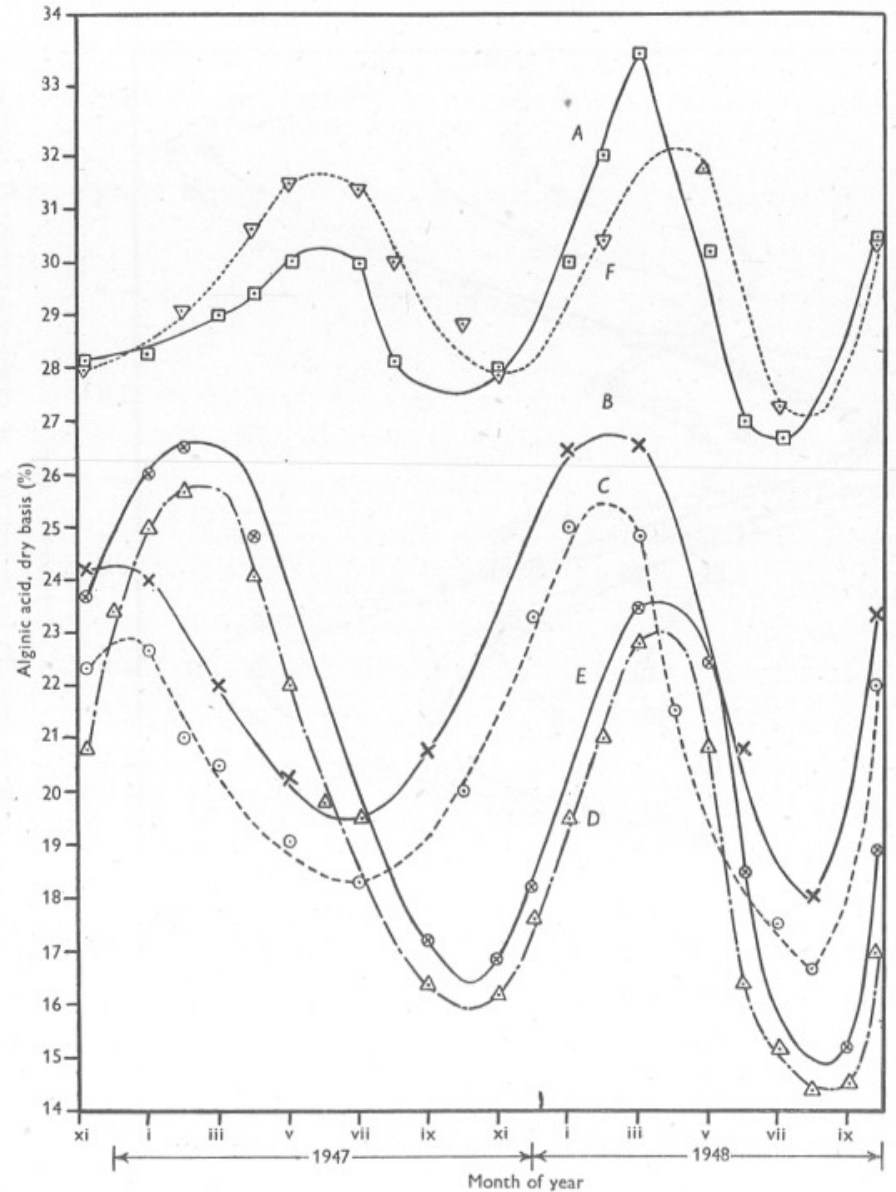

Fig. 17. Seasonal variation in alginic acid in L. digitata. A, opensea stipes; $B$, open-sea whole plant; $C$, open-sea fronds; $D$, loch fronds; $E$, loch whole plants; $F$, loch stipes.

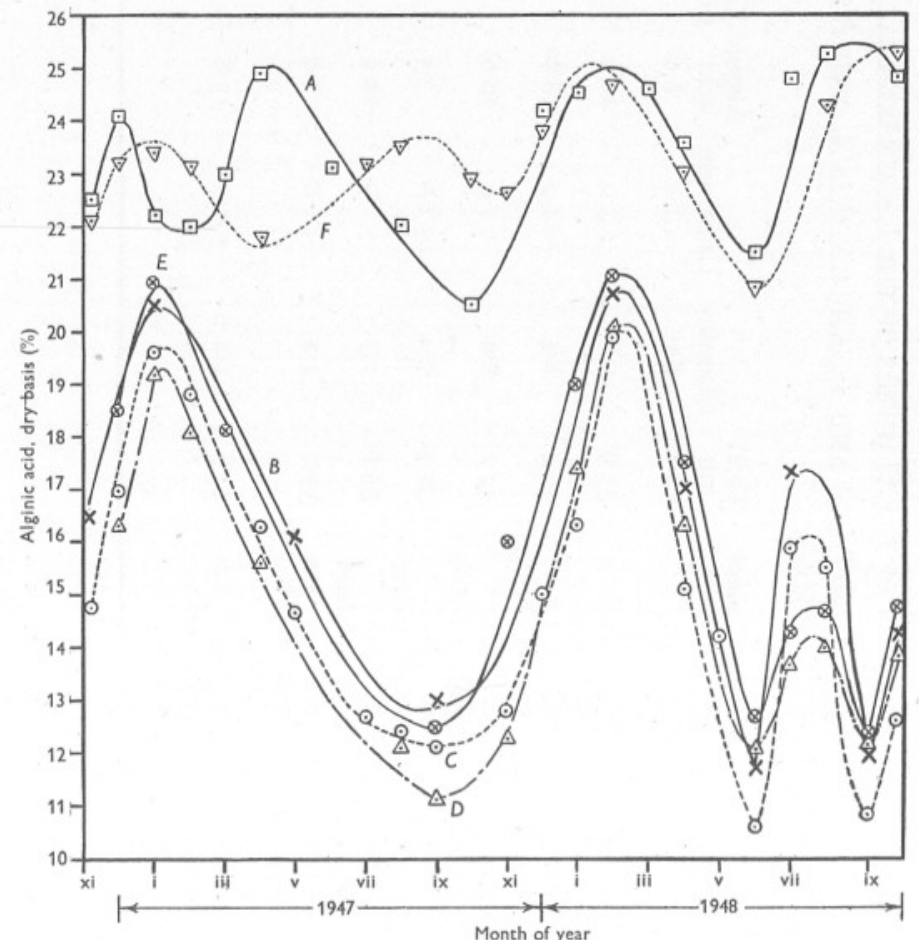

Fig. I8. Seasonal variation in alginic acid in L. saccharina. A, opensea stipes; $B$, open-sea whole plant; $C$, open-sea fronds; $D$, loch fronds; $E$, loch whole plants; $F$, loch stipes. 
outgrowths from a meristematic layer on the outside of the stipe, and once they start to form the tips can be regarded as growing tips.

It is interesting to note the low percentage of alginic acid, when determined by the standard method (Black, I948). When the method was modified so that after soaking in acid the sodium carbonate was added without filtering off the

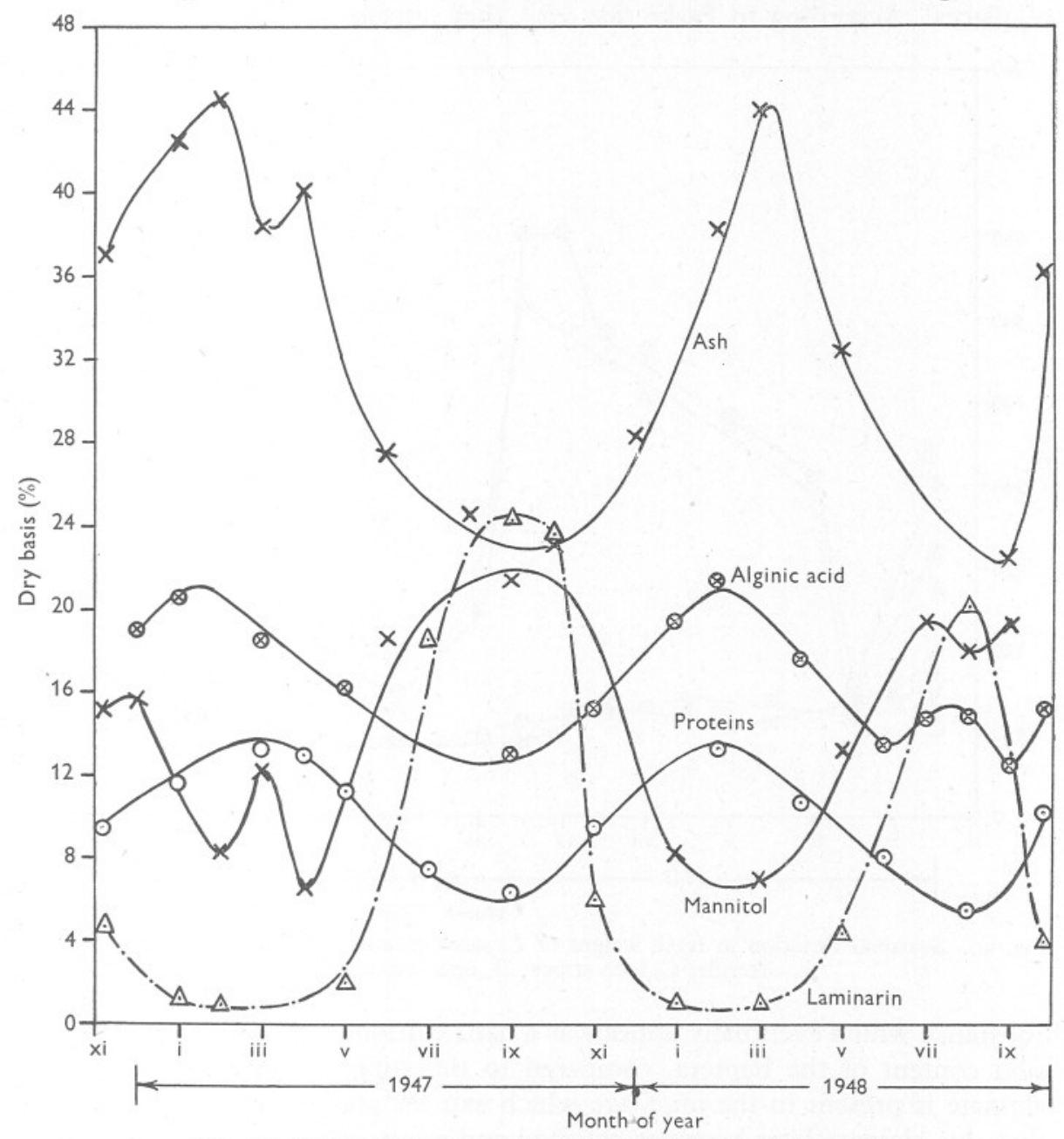

Fig. I9. Seasonal variation in L. saccharina (loch) whole plant.

weak acid solution, a result of $14.8 \%$ was obtained for the haptera of Laminaria cloustoni. When the alginic acid was determined by the carbazole method of Percival \& Ross (I948 $b$ ) a figure of $20.4 \%$ was obtained. The results indicate that in the haptera there is present either a water-soluble or a very low-grade alginate which requires further investigation. 
The results show, however, that the haptera of $L$. digitata are considerably higher in alginic acid than those of $L$. cloustoni and L. saccharina, which may account for the very firm attachment which the holdfast of $L$. digitata has for the substratum.

The haptera as they touch the substratum become attached in a number of places. According to Parke (loc. cit.) they appear to secrete some sticky

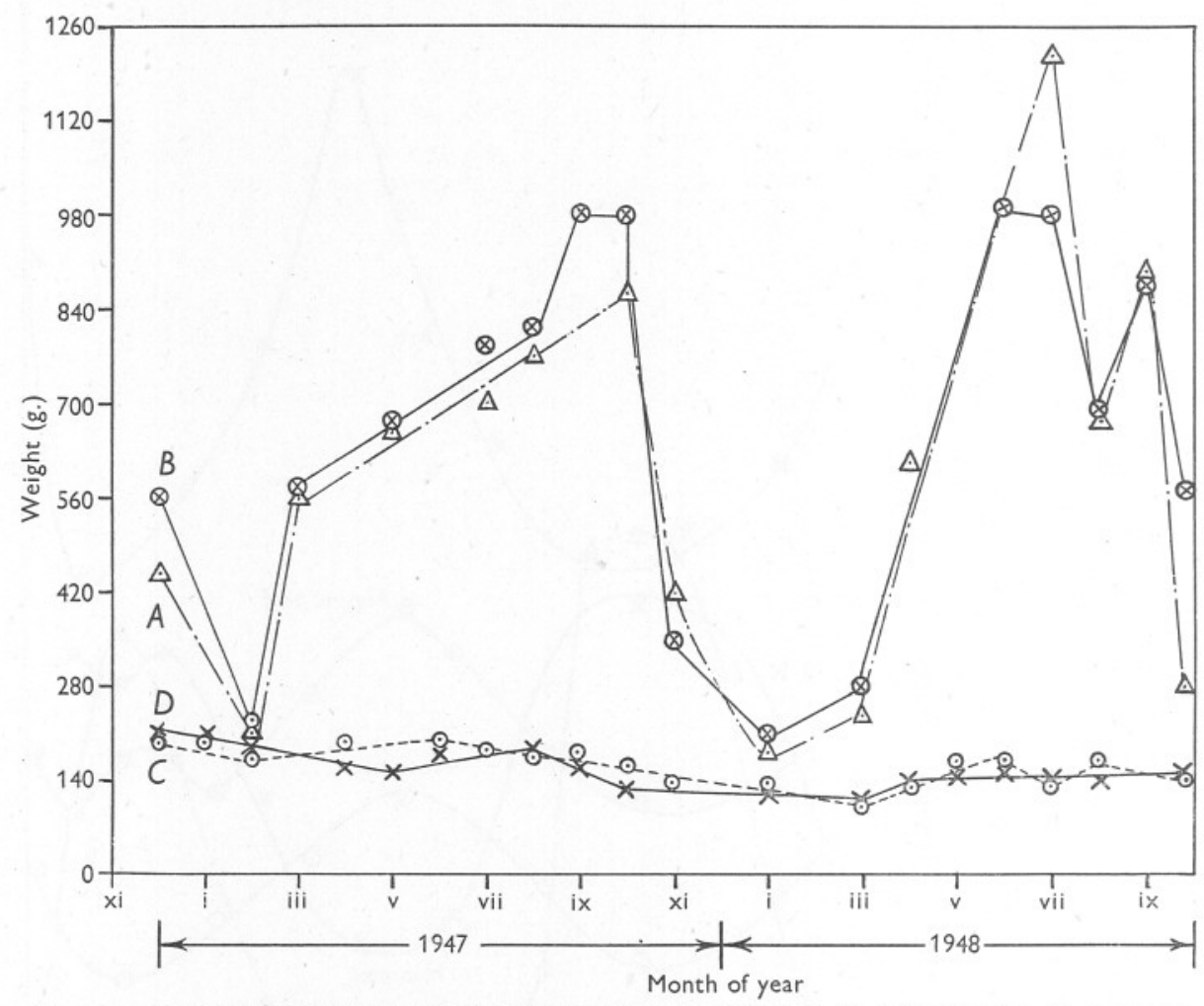

Fig. 20. Seasonal variation in fresh weight of $L$. saccharina in $A$, loch fronds; $B$, open-sea fronds; $C$, loch stipes; $D$, open-sea stipes.

substance which eventually appears as a hard chitinous layer. The low alginic acid content of the haptera, compared to the stipe, might indicate that an alginate is present in the mucilage which exudes, and there is the possibility that this alginate later becomes calcified and assists in cementing the haptera to the substratum.

\section{SUMMARY}

The seasonal variations in the total ash, crude proteins, mannitol, laminarin and alginic acid contents are given for monthly samples of the Laminariaceae, L. cloustoni, L. digitata and $L$. saccharina from November 1946 to October 
I948, samples of L. digitata and L. saccharina having been taken at different localities to determine the effect, if any, of the degree of exposure on the chemical composition.

The results agree favourably with those of the first 2 years examined and indicate that, with only a few exceptions, results might be reproducible in the corresponding season of any year, and it should be possible, therefore, to predict the approximate composition in subsequent years.

As before, the marked seasonal variations in chemical constitution occur in the fronds, where the bulk, if not all, of the photosynthesis occurs. The stipes undergo some variation parallel to that in the fronds, but within narrower limits, while laminarin is absent throughout the year.

In the fronds in the spring, mannitol is at a minimum and laminarin is absent, while the crude proteins, ash and alginic acid are at a maximum. In the autumn the reverse is true. The dry-matter content shows a corresponding variation, being at a minimum in the spring and a maximum in the autumn, but the variation is greatest in the loch samples and in L. cloustoni at Cullipool.

In the case of $L$. digitata and $L$. saccharina, the main effect of different degrees of exposure is that in the plants from the more sheltered localities (lochs) the laminarin and consequently the dry-weight contents are higher than in the more exposed samples, which might indicate 'restricted' growth in the lochs.

The fresh weight of the plants undergoes a similar seasonal variation, being at a minimum in the spring and a maximum in late summer.

A preliminary examination of the haptera has been carried out, and indicates a high inorganic nitrogen and free amino-acid content, while there is evidence of the presence of a lower grade alginate than is present in the adjacent stipe.

\section{REFERENCES}

Allsop, A., I948. Chromatographic study of meristematic plant tissues. Nature, Vol. I6I, pp. 833-5.

Astbury, W. T., I945. Structure of alginic acid. Nature, Vol. 155, pp. 667-8.

AtsuKI, K. \& TOMODA, Y., I926a. Studies on seaweeds of Japan. First report on the chemical constitution of the Laminaria. Fourn. Soc. Chem. Ind. Fapan, Vol. 29, p. $132 \mathrm{~B}$.

I $926 b$. Chemical constituents of the brown algae. Fourn. Soc. Chem. Ind. Fapan, Vol. 29, pp. 509-17, 599.

BARRY, V. C., I938. Preparation, properties and mode of occurrence of laminarin. Sci. Proc. Roy. Dublin Soc., Vol. 21, pp. 615-22.

- 1939. Constitution of laminarin. Sci. Proc. Roy. Dublin Soc., Vol. 22, pp. 59-67. I94I. Hydrolysis of laminarin. Sci. Proc. Roy. Dublin Soc., Vol. 22, pp. 423-9. I942. A new method of end group assay for laminarin. Fourn. Chem. Soc., Vol. I83, pp. $578-8 \mathrm{r}$.

Barry, V. C. \& Dillon, T., I935. Preparation and properties of alginic acid. Sci. Proc. Roy. Dublin Soc., Vol. 21, pp. 165-6. 
Barry, V. C. \& Dillon, T., I936. Preparation of alginic acid and its constitution. Sci. Proc. Roy. Dublin Soc., Vol. 21, pp. 285-7.

Berk, F. W., 1940. Recovery of mannitol from seaweed. Brit. Pat., 545,672.

BIRD, G. M. \& HAAS, P., I93I. Nature of the cell wall constituents of Laminaria spp. Biochem. Fourn., Vol. 25, pp. 403-II.

BLACK, W. A. P., I948. Seasonal variation in the chemical constitution of some of the Laminariaceae common to Scotland. Fourn. Soc. Chem. Ind., Vol. 67, pp. 165-72.

Black, W. A. P. \& Dewar, E. T., 1949. Correlation of some of the physical and chemical properties of the sea with the chemical constitution of the algae. Fourn. Mar. Biol. Assoc., Vol. xxvIII, pp. 673-99.

Colin, P. \& RICARD, R., I929. Derivatives of brown algae. Some properties of laminarin from Laminariae. Comp. Rend. Acad. Sci. Paris, T. I88, pp. I449-5I.

- 1930. Glucides and derivatives of the brown algae. Comp. Rend. Acad. Sci. Paris, T. 190, pp. 1514-I6.

CoRnec, E., I9I9. Spectrographic studies of the ash of marine plants. Comp. Rend. Acad. Sci. Paris, T. 168, pp. 513-4.

Dillon, T., I943. Utilisation of seaweed. Chem. Age, Vol. 49, pp. 279-83, 305-8.

Dillon, T. \& McGuinness, A., 1931. Alginic acid. Its mode of occurrence and constitution. Sci. Proc. Roy. Dublin Soc., Vol. 20, pp. 129-33.

Dillon, T. \& O'Tuama, T., I935. Cellulose of marine algae. Sci. Proc. Roy. Dublin Soc., Vol. 2I, pp. I47-52.

Gomez, M. L., I933. Chemical studies of algine and alginic acid. Int. Espan. Oceanograf. Nat. Resum., Ser. II, No. 74, 98 pp.

Gruzewska, M., I923. Some physical and chemical properties of laminarin. Bull. Soc. Chim. Biol., Vol. 5, pp. 216-26.

HAAS, P. \& Hill, T. G., I929. An examination of the metabolic products of certain fucoids. Biochem. Fourn., Vol. 23, pp. I00I-4.

- I93I. Preliminary note on the nitrogen metabolism of seaweeds. Biochem. Fourn., Vol. 25, pp. $1472-5$.

- 1933. Observations on the metabolism of certain seaweeds. Ann. Bot., Vol. 47, pp. $55-67$.

HaAs, P., Hill, T. G. \& Russel-Wells, B., 1938. Observations on the metabolism of certain seaweeds. On certain simple peptides occurring in marine algae. Biochem. Fourn., Vol. 32, pp. 2129-33.

Hassid, W. Z., I944. The chemistry of the carbohydrates. Ann. Rev. Biochem., Vol. I3, pp. 80-82.

HeNDRICK, J., I9I6. The value of seaweeds as raw materials for chemical industry. Fourn. Soc. Chem. Ind., Vol. 35, pp. 565-74.

HIRST, E. L., JoNES, J. K. N. \& JoNES, W. O., I939. Structure of alginic acid. Fourn. Chem. Soc., I939, pp. I880-5.

Hoagland, D. R. \& LiEB, L. L., I915. The complex carbohydrates and forms of sulphur in marine algae of the Pacific Coast. Fourn. Biol. Chem., Vol. 23, pp. $287-97$.

JonES, A. J., I922. The arsenic content of some of the marine algae. Pharm. Fourn., Vol. I09, pp. 86-7.

KIZEVETTER, I. V., I938. Chemical composition and uses of seaweeds of far eastern regions. Bull. Far East Branch Acad. Sci. U.S.S.R., No. 3I, pp. 49-I09.

KREFTING, A. \& ToRUP, R., I909. A new carbohydrate from the Laminariaceae. Pharmacia, Vol. 6, pp. I5I-3.

Kylin, H., I9I3. Biochemistry of sea algae. Ztschr. Physiol. Chem., Bd. 83, pp. I7I-97. 1915. Biochemistry of sea algae. Ztschr. Physiol. Chem., Bd. 94, pp. 337-425. 
Kylin, H., I9I8. Chemistry of seaweeds. Ztschr. Physiol. Chem., Bd. ror, pp. 236-47.

— 1944. The biochemistry of the Phaeophyceae. Kgl. Fysiograf. Sälskap. Lund, Förh., Bd. 14, pp. 226-38.

LAPICQUE, L., I9I9. Seasonal variations in the chemical composition of the marine algae. Comp. Rend. Acad. Sci. Paris, T. 169, pp. I426-8.

Le Glohhec, V. C. E. \& Herter, J. R., I940. Removal and recovery of laminarin. U.S. Patent, 2,188,092.

LUNDE, G., 1937. Seaweed as source of chemical raw materials. Ztschr. Angewandte Chemi., Bd. 50, pp. 73I-4.

MANNING, W. M. \& HARDIN, G., I944. Zanthophylls and carotenes in brown algae. Biol. Bull. Wood's Hole, Vol. 86, pp. I69-9r.

NAYloR, G. C. \& RUSSEL-Wells, B., I934. Presence of cellulose and its distribution in the cell walls of brown and red algae. Ann. Bot., Vol. 48, pp. 635-4I.

Nelson, W. L. \& Cretcher, L. H., I929. The alginic acid from Macrocystis pyrifera. fourn. Amer. Chem. Soc., Vol. 51, pp. 1914-22.

Nisizawa, K., I940. Laminarin and mannitol of brown algae. Science Repts. Tokyo Bunrika Daigaku, Vol. 5 B, pp. 9-I4.

ÖY, E., I940. Content of iron, copper, manganese and boron in seaweeds. Tids. Kemi Bergv., Vol. 20, pp. II4-I7.

PARKE, M., I948. Studies on British Laminariaceae. I. Growth in Laminaria saccharina. Fourn. Mar. Biol. Assoc., Vol. 27, pp. 65I-707.

Percival, E. G. V. \& Ross, A. G., I948a. The cellulose of marine algae. Nature, Vol. I62, pp. 895-7.

- I $948 b$. Colorimetric method for estimation of alginic acid. Fourn. Soc. Chem. Ind., Vol. 67, pp. 420-I.

RICARD, R., I93I. Nature and seasonal variation of the carbohydrates in laminaria. Bull. Soc. Chim. Biol., Vol. 13, pp. 417-35.

Russel-Wells, B., I932. Fats of brown seaweeds. Nature, Vol. I29, pp. 654-5.

SCHMIEDEBERG, W. I885. Über die Bestandtheile der Laminaria. Gesellschaft deutscher Naturforscher und Arzte, Leipzig, Tageblatt der Versammlung, No. 58, p. 427.

Speakman, J. B. \& Chamberlain, N. H., I944. Structure of alginic acid. Fourn. Soc. Dyers and Col., Vol. 60, pp. 264-72.

StANFORD, E. C. C., I883. On algin: a new substance obtained from some of the common species of marine algae. Chem. News, Vol. 47, pp. 254-7, 267-9.

— I884a. On algin. Fourn. Soc. Chem. Ind., Vol. 3, pp. 297-302.

- r884b. The economic applications of seaweed. Fourn. Soc. Arts, London, Vol. 32, pp. $717-30$.

— I886. On alginic acid and its compounds. Fourn. Soc. Chem. Ind., Vol. 5, pp. $218-2 \mathrm{I}$.

STENHOUSE, J., I844. On the occurrence of mannite in L. saccharina and other seaweeds. Fourn. Chem. Soc., Vol. 2, pp. I36-40.

SteWART, W. T. \& Lucas, H. T., I940. Oxidation of alginic acid by periodic acid. Fourn. Amer. Chem. Soc., Vol. 62, pp. I792-6.

Takahashi, E., Sirahama, K. \& Shun-Iti-TASe, I933. Chemical studies on fats of algae. Part I. Contents of fats and their properties. Fourn. Chem. Soc. Fapan, Vol. 54, pp. 619-23.

- 1935. Part II. Contents of fats and their properties. Fourn. Chem. Soc. Fapan, Vol. 56, p. 1250 .

1939. Part V. Non-volatile fatty acids of Alaria crassifolia. Fourn. Chem. Soc. fapan, Vol. 60, pp. 56-60. 
VEDRINSKII, A. I., I938. Chemical composition of industrially important seaweeds of the White Sea. Trud. Arkangel'skago Vodoroslevago Nauch.-Issledov. Inst. Vodorosli Belago Morya, pp. 6I-79.

VernadSKII, V. I., I930. The concentration of radium by plant organisms. Comp. Rend. Acad. Sci. U.S.S.R., Sect. 4, pp. 539-42.

Viel, G., I939. Sur les celluloses des algues. Comp. Rend. Acad. Sci. Paris, T. 208, pp. $532-4$.

WASSERMAN, A., I949. Cation adsorption by brown algae. The mode of occurrence of alginic acid. Ann. Bot., Vol. xIII, pp. 79-88.

WILSON, S. H. \& FieldES, M., I94I. Studies in spectrographic analysis. II. Minor elements in a sea-weed (Macrocystis pyrifera). New Zealand fourn. Sci. Tech., Vol. 23 , No. 2 B, pp. 47 B-48 B. 